\title{
The adverse health effects of waterpipe smoking in adolescents and young adults: A narrative review
}

\author{
Olorunfemi Adetona', Sarah Mok', Jenna Rajczyk², Marielle C. Brinkman², Amy K. Ferketich²
}

\begin{abstract}
Waterpipe (WP) smoking has rapidly grown in popularity in the United States and other Western countries with the fastest uptake among younger individuals. This growth has been encouraged by the misperception that WP smoke is harmless or less harmful than cigarette smoke. To better understand how WP affects the health of young people, we conducted a narrative review of the literature focusing on the adverse health effects of WP smoking in adolescents and younger adults. We searched scientific literature databases including PubMed, MEDLINE, EMBASE, and ISI Web and selected papers that met the inclusion criteria. Sixty-three papers met the inclusion criteria and were selected for review. Data were abstracted from the selected papers into a standardized table. The evidence demonstrates that WP smoking can cause acute lung infection and injury, and carbon monoxide (CO) poisoning, in adolescents and young adults. It is also associated with adverse subclinical effects in this sub-population, including oral and systemic genotoxicity, lung function decline, and the alteration of vascular and hemodynamic functions. Limited evidence that is available indicates associations with psychological and neurological effects and asthma. No identified publications examined the association between WP use and type 2 diabetes, a condition that is associated with cigarette smoking among young people. WP smoking by younger individuals can result in their hospitalization due to systemic CO poisoning and acute lung disease, and induce subclinical adverse effects in the oral cavity, pulmonary system, and in circulation, that are involved in the pathogenesis of local and systemic chronic diseases.
\end{abstract}

AFFILIATION
1 Division of Environmental
Health Sciences, College of
Public Health, The Ohio State
University, Columbus, United
States
2 Division of Epidemiology,
College of Public Health,
The Ohio State University,
Columbus, United States

CORRESPONDENCE TO

Olorunfemi Adetona. Division of Environmental Health Sciences, College of Public Health, The Ohio State University, 436 Cunz Hall, 1841 Neil Avenue, Columbus, $\mathrm{OH} 43210$, United States. E-mail: adetona.1@osu.edu

\section{KEYWORDS} waterpipe, hookah, tobacco, young adults, adolescents

Received: 23 April 2021 Revised: 25 June 2021 Accepted: 22 September 2021

\section{INTRODUCTION}

Also referred to as hookah, shisha, narghile, and hubble-bubble ${ }^{1}$, waterpipe (WP) smoking was traditionally associated with men in the Middle East ${ }^{2}$. However, its use has rapidly expanded to become a global phenomenon over the last three decades ${ }^{2}$. Much of the global growth in WP use is attributable to its relative popularity among youths and young adults $^{2-4}$. For example, $47.5 \%$ and $9.2 \%$ of young adults (aged 18-24 years), versus $15.5 \%$ and $1.2 \%$ of adults (aged $\geq 25$ years), in a 2015-2016 national US survey reported ever or current (use within the past 30 days) WP use, respectively ${ }^{5}$. Additionally, prevalence of ever or current use among middle and high school students in the National Youth Tobacco Survey (NYTS) in the US was 7.6-14.6\% and 2.5$6.4 \%$, respectively, between 2011 and $2017^{6}$.

The global expansion of WP use has been aided by the social context surrounding WP smoking, the availability of flavored WP tobacco, Internet and social media messaging, and the lack of WP-specific tobacco regulations ${ }^{2}$. The growth in its acceptance among younger individuals has also been encouraged by misconceptions about its harmfulness ${ }^{3,4,6}$. Many WP tobacco smokers believe that it is harmless or at least less harmful and less addictive than cigarette 
smoking $^{1,4}$. As can be seen in Figure 1, WPs involve smoking tobacco that is heated by charcoal in the WP head. When a user sucks on the mouthpiece of the hose that is attached to the WP, the resulting smoke bubbles through water before inhalation. Many WP tobacco smokers believe that the water in the bowl filters out the toxic agents in tobacco smoke ${ }^{1,4}$. The combination of tobacco flavoring and water in the WP bowl results in a humid, milder smoke that is less irritating compared to cigarette smoke ${ }^{1,4}$.

The lower irritation potential of WP tobacco smoke and the significantly lower draw resistance of the WP, compared to other combustible tobacco products, encourage deeper inhalation and longer smoking sessions ${ }^{1}$. The volume of smoke inhaled during a 1-hour session of WP smoking is about 200 times the volume that is drawn from smoking one cigarette $^{7,8}$. Also, one WP smoking session can yield two, five and ten times the amount of nicotine, tar, and carbon monoxide (CO), respectively ${ }^{7-9}$, and produces larger amounts of heavy metals, polycyclic aromatic hydrocarbons, and semi-volatile furans compared to yields from smoking one cigarette ${ }^{9-11}$. Therefore, the associations between WP smoking and chronic respiratory diseases, cardiometabolic diseases, lung cancer, oral and gastrointestinal cancers, and other cancers are not unexpected and are similar to the adverse health effects of cigarette smoking ${ }^{12,13}$.

Although, most of the global growth in the popularity of WP smoking has been among youth and young adults, few studies of its adverse health effects have been conducted among these age groups. We reviewed the available evidence of the health impacts of WP use among youth/young adults (aged 14-34 years, following the US Census categorization of young adults $)^{14}$. While related reviews including recent publications have been conducted ${ }^{12,13,15-17}$, none has focused on adverse effects observed among younger individuals.

\section{Literature search}

Since there are a limited number of studies of the adverse health effects of WP smoking among adolescents and young adults, all epidemiological studies, including case studies, were included in this narrative review. Reviewed studies met the following criteria: 1) must include a WP smoking group and some quantification (at least binary yes/no) of WP smoking; 2) must have collected information about adverse physiological, subclinical or clinical outcomes from study participants; 3 ) must have determined the association between WP smoking and the adverse health outcome; 4) must have reported the association between WP smoking and the health outcome(s) specific to a study group that is all or mostly adolescents/youths/young adults; and 5) must have been published in English.

Four scientific research databases including PubMed, MEDLINE, EMBASE, and ISI Web Science were electronically searched between April and June 2020 for potentially eligible peer-reviewed articles. The keywords used consisted of synonyms of WP, smoking-related health effects, and terms identifying the age group of interest as outlined below:

- Keyword Group 1 (WP synonyms): waterpipe, hookah, narghile, shisha;

Figure 1. A waterpipe (the charcoal, for heating, and foil are placed on top of the tobacco in the head, but are not pictured)

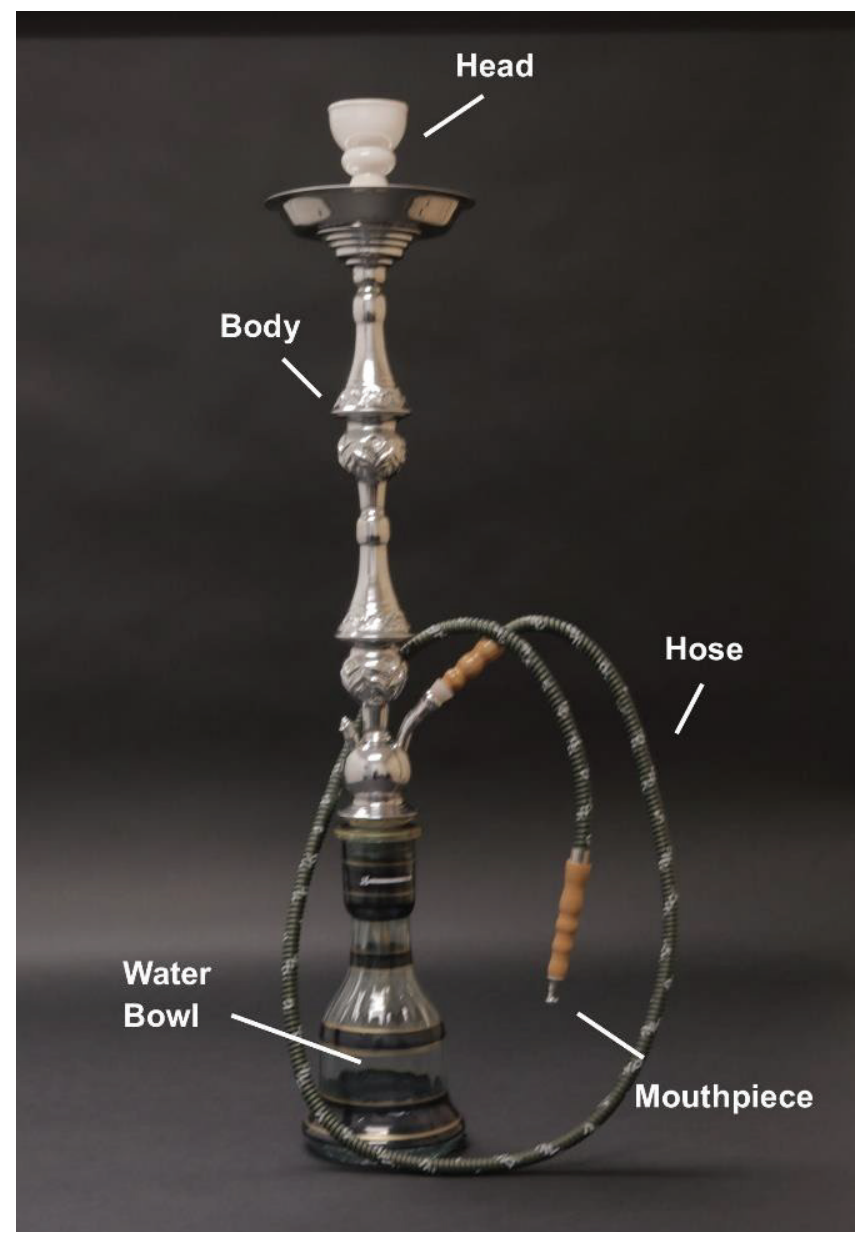


- Keyword Group 2 (Smoking-related health effects): health effects, oral, infection, pulmonary, respiratory, lung function, cardiovascular, cognitive, neurological, psychological, developmental, oxidative stress, inflammation, DNA damage, genotoxicity, cancer, leukemia, sarcoma; and

- Keyword Group 3 (Age group terms): adolescent, youth, young adult.

Searches were made using all combinations of the keywords from the three groups with one keyword from each group. For example, ['waterpipe', 'cardiovascular', 'adolescent'] was one of the search strings. The search strings did not include Boolean operators. A total of 555 unique results were identified after duplicates were removed.

One reviewer screened the identified paper for selection, according to the outlined criteria. The selections were then reviewed by another reviewer. Data were abstracted from each selected paper by three of the reviewers into a standardized form (Tables 1 to 5 ). The abstracted data were thereafter reviewed by one of the reviewers for correctness.

We identified a total of 65 papers that satisfied the selection criteria. Twelve of the studies reported on oral health effects, 16 on pulmonary health effects, 18 on cardiovascular health effects, 10 on psychological/ neurological health effects, and 16 on general physiological responses. Of the 65 papers, 52 were either cross-sectional or pre-post studies, 10 were case studies, and 3 were cohort studies. Forty-one of the studies were conducted in the Middle East, 4 in Europe, 14 in North America, 1 in South America, 2 in Asia, and 1 in the Pacific.

\section{DEVELOPMENTS}

\section{Effects in the oral cavity}

The following effects of WP smoking have been studied in the oral cavity in young adults: physiological and biochemical changes in saliva ${ }^{18,19}$; inflammation and cytological effects including chromosomal aberrations in the oral mucosa ${ }^{20-26}$; oral infection and alteration of the oral microbiome ${ }^{24,27}$; and impairment of periodontal health ${ }^{28-30}$ (Table 1). The evidence indicates that WP smoking impairs oral health among young adults, and the demonstration of its genotoxicity in oral mucosal cells is consistent across studies. WP smoking may also alter saliva biochemistry and the oral microbiome, and results suggest that it is associated with tooth and periodontal diseases.

\section{Genotoxicity}

Indicators of cell death (apoptosis and necrosis) including pyknosis, karyorrhexis, and karyolysis are consistently higher in buccal cells of WP smoking young adults compared to non-smoking controls ${ }^{24-26}$. Similar results have been observed for markers of DNA damage including binucleation, micronuclei, broken eggs, nuclear buds, and chromosome breakage, and chromosome/chromatid fragments and gaps ${ }^{20,21,23,25,26}$. In one study, a greater degree of DNA damage as indicated by micronucleus frequency in exfoliated buccal epithelial cells was observed among persons who exclusively smoked WP compared to those who exclusively smoked cigarettes ${ }^{23}$. Also, micronucleus frequency was associated with the frequency of WP smoking among young adults in a study that did control for cigarette smoking ${ }^{22}$. However, repair index, which was assessed as the ratio of nuclear changes that are evident of both apoptosis and necrosis (karyorrhexis and karyolysis) to nuclear changes that are evident of damage (broken eggs and micronuclei), was 0.6-fold lower in the buccal cells of WP smokers compared to non-smokers ${ }^{26}$. Furthermore, cytometric alterations indicating premalignant and malignant lesions including changes in nuclear size and shape, and increase in the nuclear to cytoplasm ratio were observed in buccal, tongue and mouth floor mucosa cells of WP smokers compared to non-smoking controls. These observations in WP smokers were accompanied by increased inflammation in cytological samples of the mucosa cells of the three oral areas ${ }^{24}$.

\section{Effects on saliva biochemistry and oral microbiome}

Changes in saliva that can impair oral health have been observed in WP smokers ${ }^{18,19}$. Although, stimulated saliva $\mathrm{pH}$ was similar, its buffering capacity was lower among young adult WP smokers compared to age-matched non-smoking controls ${ }^{19}$. This suggests a WP smoke-mediated impairment in the capacity of saliva to protect against enamel demineralization and dental caries ${ }^{19}$. Also, results indicate reduced saliva antioxidant capacity in WP smokers ${ }^{18}$. Peroxidase and 2,2-diphenyl-1-picryl-hydrazyl-hydrate (DPPH) activities were less increased and more reduced, 
Table 1. Studies of oral effects of WP smoking in adolescents and young adults

\begin{tabular}{|c|c|c|c|c|c|c|}
\hline $\begin{array}{l}\text { Authors } \\
\text { Year }\end{array}$ & Study design & $\begin{array}{l}\text { Study participant } \\
\text { characteristics }\end{array}$ & $\begin{array}{l}\text { Exposure } \\
\text { measures }\end{array}$ & Outcomes of interest & Key results & Methodological information \\
\hline $\begin{array}{l}\text { Arazi et al. }{ }^{25} \\
2019\end{array}$ & Cross-sectional & $\begin{array}{l}\mathrm{N}=23(11 \text { WPS, } 12 \mathrm{C}) \\
23.63 \pm 2.90 \text { years for } W P S \\
22.66 \pm 2.90 \text { years for } \mathrm{C} ; 100 \% \\
\text { female - all sedentary }\end{array}$ & WP smoking & $\begin{array}{l}\text { Saliva biomarkers pre- } \\
\text { post aerobic exercise } \\
\text { (AE) }\end{array}$ & $\begin{array}{l}\text { C > WPS for saliva flow rate (SFR) } \\
\text { at all times (SFR only declined } \\
\text { immediately after AE in WPS); C } \\
>\text { WPS for increase in peroxidase } \\
\text { and decrease in DPPH activities } \\
\text { immediately after AE; no differences } \\
\text { for uric acid. }\end{array}$ & $\begin{array}{l}\text { Self-reported WPS; convenience sample; small } \\
\text { sample size and no control for confounding - } \\
\text { participants in both groups were similar in age, } \\
\text { height, weight, and BMI. }\end{array}$ \\
\hline $\begin{array}{l}\text { Dehghan } \\
\text { Nezhad et } \\
\text { al. }^{21} \\
2020\end{array}$ & Cross-sectional & $\begin{array}{l}\mathrm{N}=60(30 \text { WPS and } 30 \mathrm{C}) ; 20-50 \\
\text { years (WPS } 26.83 \pm 3.74 \text { years } \\
\text { with } 25 \text { being } 20-30 \text { years } \\
\text { and } 5 \text { being } 30-40 \text { years and } \\
\mathrm{C} 28 \pm 7.88 \text { years with } 23 \text { being } \\
20-30 \text { years and } 5 \text { being } 30-40 \\
\text { years); } 100 \% \text { males; Tehran, Iran }\end{array}$ & $\begin{array}{l}\text { WP smoking; } \\
\text { WP smoking } \\
\text { duration and } \\
\text { frequency }\end{array}$ & $\begin{array}{l}\text { Genotoxicity in buccal } \\
\text { cells }\end{array}$ & $\begin{array}{l}\text { Micronucleus frequency - WPS > C; } \\
\text { WP smoking frequency associated } \\
\text { with micronucleus frequency. }\end{array}$ & $\begin{array}{l}\text { Self-reported exposure; controlled for possible } \\
\text { confounding by excluding persons that were } \\
\text { farmers, worked in arsenic industries, ever } \\
\text { smoked > } 100 \text { cigarettes, had history of drug use, } \\
\text { had dental radiation, had beam exposure, had } \\
\text { systemic disease, or had oral legions); persons in } \\
\text { WPS and C groups not from the same population. }\end{array}$ \\
\hline $\begin{array}{l}\text { Eker et al. }{ }^{22} \\
2016\end{array}$ & Cross-sectional & $\begin{array}{l}\mathrm{N}=60 \text { ( } 30 \text { WPS and } 30 \mathrm{C}) ; 18-25 \\
\text { years; Sex distribution of both } \\
\text { groups were similar; Turkey }\end{array}$ & WP smoking & Genotoxicity & $\begin{array}{l}\text { WPS > C for micronuclei and } \\
\text { binucleus cell frequencies. }\end{array}$ & $\begin{array}{l}\text { Self-reported exposure; participant selection } \\
\text { approach not stated; no stated control of } \\
\text { confounding. }\end{array}$ \\
\hline $\begin{array}{l}\text { Jafari and } \\
\text { Bigdoli } \\
2017\end{array}$ & Cross-sectional & $\begin{array}{l}\mathrm{N}=20 ; 25.2 \pm 3.67 \text { years; } 60 \% \\
\text { male; Tehran, Iran }\end{array}$ & WP frequency & $\begin{array}{l}\text { Genotoxicity in buccal } \\
\text { cells }\end{array}$ & $\begin{array}{l}\text { Micronucleus frequency associated } \\
\text { with frequency of WP use }(p=0.021) \text {. }\end{array}$ & $\begin{array}{l}\text { Self-reported WP smoking; convenience sample; } \\
\text { no control for confounding and no true control } \\
\text { participant. }\end{array}$ \\
\hline $\begin{array}{l}\text { Khemiss et } \\
\text { al. }^{30} \\
2016\end{array}$ & Cross-sectional & $\begin{array}{l}\mathrm{N}=120(60 \text { WPS, } 60 \mathrm{CS}) ; 28 \pm 4 \\
\text { years for WPS, } 27 \pm 3 \text { years for } \\
\mathrm{CS} ; 100 \% \text { male; Tunisia }\end{array}$ & WP smoking & $\begin{array}{l}\text { Periodontal status } \\
\text { (plaque index, } \\
\text { periodontal bone height } \\
{[\mathrm{PBH}] \text { ) }}\end{array}$ & $\begin{array}{l}\text { WPS }>\text { CS for plaque index } \\
(1.84 \pm 0.73 \text { vs } 1.54 \pm 0.70) ; \mathrm{PBH} \text { similar } \\
\text { for both groups }\end{array}$ & $\begin{array}{l}\text { Self-reported WPS; convenience sample; no } \\
\text { totally non-exposed control; exclusion based on } \\
\text { less tobacco use, morbidity, teeth }<20 \text {, radiation } \\
\text { treatment and medication use; matched based on } \\
\text { age, tobacco use, tooth brushing frequency. }\end{array}$ \\
\hline $\begin{array}{l}\text { Khemiss et } \\
\text { al. }{ }^{26} \\
2017\end{array}$ & Cross-sectional & $\begin{array}{l}\mathrm{N}=72(36 \text { WPS, } 36 \mathrm{C}) ; 23 \pm 4 \\
\text { years, } 22 \pm 3 \text { years; } 100 \% \text { males; } \\
\text { Tunisia }\end{array}$ & WP smoking & $\begin{array}{l}\text { Saliva physiological and } \\
\text { biochemical parameters }\end{array}$ & $\begin{array}{l}\text { Baseline } \mathrm{pH} \text { and saliva flow rate } \\
\text { similar for both groups; WPS }<\mathrm{C} \text { for } \\
\text { buffering capacity. }\end{array}$ & $\begin{array}{l}\text { Self-reported WPS; convenience sampling; } \\
\text { exclusion based on less tobacco use, morbidity, } \\
\text { radiation treatment and medication use, intra- } \\
\text { oral appliances. }\end{array}$ \\
\hline
\end{tabular}


Table 1. Continued

\begin{tabular}{|c|c|c|c|c|c|c|}
\hline $\begin{array}{l}\text { Authors } \\
\text { Year }\end{array}$ & Study design & $\begin{array}{l}\text { Study participant } \\
\text { characteristics }\end{array}$ & $\begin{array}{l}\text { Exposure } \\
\text { measures }\end{array}$ & Outcomes of interest & Key results & Methodological information \\
\hline $\begin{array}{l}\text { Khemiss et } \\
\text { al. }{ }^{29} \\
2019\end{array}$ & Cross-sectional & $\begin{array}{l}\mathrm{N}=144 \text { (74 WPS, } 74 \text { CS); 100\% } \\
\text { male; Tunisia }\end{array}$ & WP smoking & $\begin{array}{l}\text { Periodontal status } \\
\text { (gingival index, plaque } \\
\text { index, decayed/ } \\
\text { missing/filled teeth } \\
\text { [DMFT], probing pocket } \\
\text { depth, tooth mobility, } \\
\text { periodontal disease, } \\
\text { dentist visits) }\end{array}$ & $\begin{array}{l}\text { WPS }<\text { CS for gingival index, probing } \\
\text { pocket depth and periodontal } \\
\text { disease; both groups similar for DMFT, } \\
\text { plaque index, tooth mobility and } \\
\text { number of missing teeth. }\end{array}$ & $\begin{array}{l}\text { Self-reported WPS; convenience sample; no } \\
\text { totally non-exposed control; exclusion based on } \\
\text { less tobacco use, morbidity, teeth }<20 \text {, radiation } \\
\text { treatment and medication use; matched based on } \\
\text { age, tobacco use, tooth brushing frequency. }\end{array}$ \\
\hline $\begin{array}{l}\text { Rajabi- } \\
\text { Moghaddam } \\
\text { et al. }{ }^{23} \\
2020\end{array}$ & Cross-sectional & $\begin{array}{l}\mathrm{N}=90(30 \text { WPS, } 30 \mathrm{CS}, 30 \\
\mathrm{C}) ; 24.7 \pm 6.3 \text { years for WPS, } \\
23.8 \pm 6.9 \text { years for } \mathrm{CS}, 22.6 \pm 5.3 \\
\text { years for } \mathrm{C} ; 100 \% \text { male; location } \\
\text { unspecified }\end{array}$ & WP smoking & $\begin{array}{l}\text { Genotoxicity (buccal } \\
\text { cells) }\end{array}$ & $\begin{array}{l}\text { WPS }>C S \text { C for number of } \\
\text { micronuclei; WPS }>C \text { for number } \\
\text { of cells with micronuclei (MNF: } \\
\text { micronucleus frequency) }\end{array}$ & $\begin{array}{l}\text { Self-reported exposure; groups matched by age } \\
\text { and sex, exclusion of persons with visible lesions } \\
\text { or history of malignancy, chronic systemic disease, } \\
\text { use of alcohol and other substances. }\end{array}$ \\
\hline \multirow[t]{2}{*}{$\begin{array}{l}\text { Seifi et al. }{ }^{18} \\
2014\end{array}$} & \multirow[t]{2}{*}{ Cross-sectional } & \multirow[t]{2}{*}{$\begin{array}{l}\mathrm{N}=120(4040 \text { WPS, } 40 \mathrm{CS} \\
\text { and } 40 \mathrm{C}) ; 20-40 \text { years (WPS } \\
30.15 \pm 6.02 \text { years, CS } 30.32 \pm 5.69 \\
\text { years, C } 30.3 \pm 5.83 \text { years) ; } 100 \% \\
\text { males; Babol, Iran }\end{array}$} & \multirow[t]{2}{*}{ WPS smoking } & $\begin{array}{l}\text { Cytological examination } \\
\text { of oral mucosa }\end{array}$ & $\begin{array}{l}\text { Nuclear size - CS }>\text { WPS }>C \text { in buccal, } \\
\text { tongue and mouth floor mucosa; } \\
\text { cytoplasm size - CS }<\text { WPS }<C \text { in } \\
\text { buccal, tongue and mouth floor } \\
\text { mucosa; nuclear/cytoplasm size ratio } \\
\mathrm{CS}>\text { WPS }>\text { C in buccal, tongue and } \\
\text { mouth floor mucosa; ferret ratio - CS } \\
>\text { WPS }>\text { C in buccal, tongue and } \\
\text { mouth floor mucosa; no differences } \\
\text { in karyorrhexis, vacuolization or cells } \\
\text { with multilobular nuclei. }\end{array}$ & \multirow[t]{2}{*}{$\begin{array}{l}\text { Self-reported exposure status; convenience } \\
\text { sampling, groups from different populations; } \\
\text { control of potential confounders including age } \\
\text { and sex via matching and restriction via eligibility } \\
\text { criteria; WPS and CS groups from populations } \\
\text { that are different from C group. }\end{array}$} \\
\hline & & & & Oral candida & $\begin{array}{l}\text { Higher percentage of WPS + CS } \\
\text { compared to C in buccal, tongue and } \\
\text { mouth floor mucosa. }\end{array}$ & \\
\hline
\end{tabular}


Table 1. Continued

\begin{tabular}{|c|c|c|c|c|c|c|}
\hline $\begin{array}{l}\text { Authors } \\
\text { Year }\end{array}$ & Study design & $\begin{array}{l}\text { Study participant } \\
\text { characteristics }\end{array}$ & $\begin{array}{l}\text { Exposure } \\
\text { measures }\end{array}$ & Outcomes of interest & Key results & Methodological information \\
\hline
\end{tabular}

Oral cavity inflammation Higher percentage of WPS + CS

compared to $\mathrm{C}$ in buccal, tongue and mouth floor mucosa.

Shakhatreh Cross-sectional N=100 (59 WPS, 41 C);

et al. ${ }^{27}$

2018 $23.98 \pm 2.77$ years for WPS, $24.14 \pm 4.37$ years for $C_{i} 74.5 \%$ and $65.9 \%$ male for WPS and $C$ resp.; Irbid City, Jordan

Silveira et Cross-sectional $\quad \mathrm{N}=80$ (40 WPS, $40 \mathrm{C}$ );

al. ${ }^{19}$ $22.55 \pm 3.02$ years for WPS $20.00 \pm 3.15 ; 50 \%$ male for both groups

Taghibakhsh Cross-sectional $\mathrm{N}=72$ participants (36 WPS and et al. ${ }^{20}$

2019 $36 \mathrm{C})$; mean age $27.3 \pm 5.9$ years in WPS group and $29.9 \pm 6.1$ in C: 100\% male; Tehran, Iran

\begin{tabular}{|c|c|c|c|}
\hline $\begin{array}{l}\text { Al-Belasy }{ }^{31} \\
2004\end{array}$ & $\begin{array}{l}\text { Prospective } \\
\text { cohort }\end{array}$ & $\begin{array}{l}\mathrm{N}=300 \text { (100 each of WPS, CS, } \\
\mathrm{C}) ; 22-39 \text { years for WPS, 20-38 } \\
\text { years for } \mathrm{CS}, 20-37 \text { years for } \mathrm{C} \text {; } \\
100 \% \text { male; Egypt }\end{array}$ & $\begin{array}{l}\text { WP smoking } \\
\text { and WP } \\
\text { frequency }\end{array}$ \\
\hline
\end{tabular}

*WPS: waterpipe smokers. CS: cigarette smokers. C: control.
WP smoking Sub-gingiva and oral cavity microbial flora

Sub-gingiva - WPS $>C$ for frequency of Candida Albicans; Acetinobacter and Moraxella spps. only present

in WPS; WPS < C for frequency of Fusobacterium Nucleatum. Oral cavity - WPS > C for CFU of black pigmented bacteria. No differences with Campylobacter, Viridians group Streptococci,

Enterobacteriaceae, Staphylococcus Aureus

WPS $>$ C for self-reported oral

infection.

Karyolitic cells, karyorrhetic

cells, micronuclei, pyknotic cells,

binucleated cells, cells with nuclear buds - WPS > C $1.29 x, 1.58 x, 5.54 x_{1}$ $2.00 \mathrm{x}, 2.17 \mathrm{x}, 3.87 \mathrm{x}$ respectively: differentiated cells - WPS $<$ C 0.94x.

Genotoxicity in buccal WPS $>C$ for micronuclues, cells

karyorrhexis, karyolysis and broken eggs with mean frequencies 1.8-2.5 folds of $\mathrm{C}$ group; WPS $<\mathrm{C}$ for repair index at 0.6 -fold of $C$

Dry socket on third molar tooth removal

WPS, CS > C for incidence of dry socket; dose response relationship observed with regards to number o WP sessions per day.
Self-reported WPS; convenience sample; exclusion based on bleeding gum, oral disease, medication.

Self-reported exposure; participant selection unspecified; participants matched on age, gender and alcohol use with control for age and gender; CS and ex-smokers excluded.

Self-reported exposure; sampling technique not described except stated as 'objectivebased sampling'; excluded persons who smoked cigarettes, consumed alcohol and/or drugs, had systemic disease, exposed to chemical agents, had radiotherapy for head and/or neck; did not control for confounders otherwise.

Self-reported WPS, convenience sample but from same dentist practice; excluded patients taking/ needing antibiotic prior to procedure; did not control for other potential risk factors for dry socket. 
respectively, in WP smoking young adults following exhaustive acute exercise, which is an oxidative stress inducing activity ${ }^{18}$.

WP smoking may also alter the oral microbiome ${ }^{27}$. The frequency of detection of Candida albicans, the fungus that causes oral thrush, was higher in the subgingival plaque of young adult WP smokers compared to age-matched non-smoking controls. Acinetobacter and Moraxella spp. in the subgingival plaque were only detected in the WP smokers, while the colony forming unit (CFU) of black-pigmented bacteria Porphyromonas gingivalis and Prevotella intermedia was higher in their oral cavity samples (cheek, teeth, and tongue). Some Acinetobacter and Moraxella species cause respiratory airway infections, while both black-pigmented bacteria species are periodontal pathogens ${ }^{27}$. Meanwhile, the detection frequency of Fusobacterium nucleatum, a ubiquitous and mostly commensal microbe in the oral cavity, was lower in the subgingival plaque of the WP smokers ${ }^{27,31}$. The frequency of candida detection in cytological smears of the cheeks, tongue and floor of the mouth of WP smokers was similar to the frequency among cigarette smokers, but lower than the observations made among age- and sex-matched non-smoking young adult controls in another study ${ }^{24}$.

\section{Tooth and periodontal effects}

Khemiss et al. ${ }^{29}$ reported similar (decayed/missing/ filled teeth, plaque index, and tooth mobility) or better (gingival index, probing pocket depth, and periodontal disease) degrees for indicators of teeth and gum health in young adult WP smokers compared to cigarette smokers. However, the same authors had observed higher plaque index in WP smokers in a prior study ${ }^{30}$. Neither study included non-smoking controls for comparison. In another study, young adult WP smokers had a similar likelihood of developing an occurrence of oral dry socket (a very painful condition caused by the dislodgement of the clot and the disruption of the healing at a tooth extraction site) after the extraction of the third mandibular molar tooth compared to cigarette smokers, and a three times higher likelihood compared to non-smokers ${ }^{28}$. The incidence of oral dry socket also increased with smoking frequency, and the outcome was five times more likely to be observed in young adults who smoked WP twelve times per day compared to those who smoked three times per day ${ }^{28}$.

Comments about studies of effects in the oral cavity

All the studies of the adverse oral effects of WP smoking in young adults included age- and sexmatched positive and/or negative controls, i.e. cigarette smoking and/or non-smoking groups, which sometimes excluded males or females. However, differences in outcomes based on sex were not investigated in any of the studies. Most of the studies excluded persons with chronic systemic disease or previous oral infection or disease, use of medication and/or radiation exposure. However, there was potential for residual confounding of the results by factors such as consumption of alcohol and confections, environmental chemical exposures, and oral hygiene. All but one of the studies were conducted in Middle Eastern countries ${ }^{25}$. Smoking was self-reported and not objectively measured in all the studies. Lastly, dose-response relationship was assessed in only two studies with an observation that micronucleus frequency in the oral cavity increased in association with a higher frequency of WP usage $\mathrm{e}^{20,22}$.

\section{Pulmonary effects}

Study results (Table 2) indicate that WP smoking is associated with changes in the molecular milieu (genetic material) and cellular composition in the lungs, decrements in lung function, and respiratory symptoms among adolescents and/or young adults.

\section{Molecular and cellular effects}

Associations between WP smoking and epigenetic modifications, which in some cases overlapped with differential gene expression (mRNA transcripts), have been observed ${ }^{32}$. Walters et al. ${ }^{32}$ reported that there was at least a 1.5 -fold difference in the degree of methylation of the DNA in 623 unique genes in the cells of the small airway epithelium (SAE) of 'light' ( $\leq 5$ sessions per week) young adult users of WP, relative to non-smoking controls. Xenobiotic metabolism and cellular signaling (e.g. aryl hydrocarbon and G-coupled receptors), which are associated with cigarette smoking and smokingassociated pulmonary disease, were among the biological pathways that were mostly impacted by the observed differential methylation. Furthermore, there were differences in the expression of $11.3 \%$ 
Table 2. Studies of respiratory effects of WP smoking in adolescents and young adults

\begin{tabular}{|c|c|c|c|c|c|}
\hline $\begin{array}{l}\text { Authors } \\
\text { Year }\end{array}$ & Study design & $\begin{array}{l}\text { Study participant } \\
\text { characteristics }\end{array}$ & $\begin{array}{l}\text { Exposure } \\
\text { measures }\end{array}$ & Outcomes of interest & Key results \\
\hline $\begin{array}{l}\text { Alaska }^{44} \\
2019\end{array}$ & Case study & $\begin{array}{l}\text { 22-year-old male; Saudi } \\
\text { Arabia }\end{array}$ & WP smoking & $\begin{array}{l}\text { Spontaneous } \\
\text { pneumomediastinum }\end{array}$ & $\begin{array}{l}\text { Pneumomediastinum after smoking WP } \\
\text { for the first time. }\end{array}$ \\
\hline $\begin{array}{l}\text { Annakkaya } \\
\text { et al. }{ }^{46} \\
2018\end{array}$ & Case study & 22-year-old male; Turkey & WP smoking & $\begin{array}{l}\text { Acute eosinophilic } \\
\text { pneumonia }\end{array}$ & $\begin{array}{l}\text { Acute eosinophilic pneumonia consequent } \\
\text { upon WP smoking for the prior } 2 \text { months. }\end{array}$ \\
\hline $\begin{array}{l}\text { Brosh- } \\
\text { Nissimov et } \\
\text { al. }{ }^{48} \\
2019\end{array}$ & Case study & $\begin{array}{l}\text { 29-year-old male; Israel - } \\
\text { subject had travelled to Goa, } \\
\text { India }\end{array}$ & WP smoking & Respiratory infection & $\begin{array}{l}\text { Meliodiosis - chronic cavitary pulmonary } \\
\text { infection due to B. pseudomallei } \\
\text { suspected from using well water for WP } \\
\text { smoking. }\end{array}$ \\
\hline $\begin{array}{l}\text { Choe et al. }{ }^{45} \\
2018\end{array}$ & Case study & $\begin{array}{l}\text { 19-year-old male; New } \\
\text { Zealand - subject moved } \\
\text { from Fiji }\end{array}$ & WP smoking & $\begin{array}{l}\text { Granulomatous lesions in } \\
\text { the lungs }\end{array}$ & $\begin{array}{l}\text { Lesions observed consequent upon } \\
\text { following regular WP smoking during } \\
\text { prior } 3 \text { months; resolution of lesions after } \\
\text { smoking cessation. }\end{array}$ \\
\hline $\begin{array}{l}\text { Kang et al. }{ }^{47} \\
2016\end{array}$ & Case study & $\begin{array}{l}\text { male in 20s; United States } \\
\text { - subject moved from Saudi } \\
\text { Arabia }\end{array}$ & WP smoking & Diffuse lung opacity & $\begin{array}{l}\text { Acute eosinophilic pneumonia } \\
\text { characterized by progressive lung opacity, } \\
\text { inflamed mucosa with accumulation of } \\
\text { eosinophils; tachycardia, tachypnea, high } \\
\text { WBC count. }\end{array}$ \\
\hline $\begin{array}{l}\text { Marchetti et } \\
\text { al. }{ }^{9} \\
2020\end{array}$ & Case study & $\begin{array}{l}\text { 20-year-old male; } \\
\text { Switzerland }\end{array}$ & WP smoking & Respiratory infection & $\begin{array}{l}\text { Infection with M. tuberculosis after } \\
\text { regular WP smoking with no other risk } \\
\text { factor present. }\end{array}$ \\
\hline $\begin{array}{l}\text { Hawari et } \\
\text { al. }^{38} \\
2013\end{array}$ & Cross-over & $\begin{array}{l}\mathrm{N}=24 \text { ( } 24 \text { WPS); all } \\
\text { participants } 18-26 \text { years } \\
\text { (mean } 20.4 \text { years); } 100 \% \\
\text { male; Jordan }\end{array}$ & $\begin{array}{l}\text { WP smoking } \\
\text { session }\end{array}$ & $\begin{array}{l}\text { Spirometry, cardiopulmonary } \\
\text { exercise test }\end{array}$ & $\begin{array}{l}\text { FEF25-75\%, baseline respiratory rate, } \\
\text { Borg scale at mid and peak exercise } \\
\text { increased post WPS session. }\end{array}$ \\
\hline $\begin{array}{l}\text { Fedele et } \\
\text { al. }{ }^{50} \\
2016\end{array}$ & Cross-sectional & $\begin{array}{l}\mathrm{N}=32921 \text {; all participants } \\
\text { 9th-12th grade; } 51.3 \% \text { male; } \\
39.1 \% \text { White, } 22.3 \% \text { Black, } \\
\text { 30.6\% Hispanic, } 8.0 \% \text { Others; } \\
\text { Florida }\end{array}$ & WP Smoking & Self-reported asthma & $\begin{array}{l}\text { OR=1.32 of current use of WP among } \\
\text { asthmatics. }\end{array}$ \\
\hline
\end{tabular}

Methodological information

Case study

for the first time.

Case study

Meliodiosis - chronic cavitary pulmonary Case study

infection due to B. pseudomallei

suspected from using well water for WP

following regular WP smoking during

prior 3 months; resolution of lesions after

Case study

Case study

inflamed mucosa with accumulation of

WBC count.

Case study

WP smoking session; convenience sample: excluded participants with abnormal cardiovascular health measures, fever, acute upper or lower respiratory tract infections.

No control for confounders, self-reported

WP smoking and outcome. 
Table 2. Continued

\begin{tabular}{l|l|l}
$\begin{array}{l}\text { Authors } \\
\text { Year }\end{array}$ & Study design & \multicolumn{1}{c}{$\begin{array}{c}\text { Study participant } \\
\text { characteristics }\end{array}$} \\
$\begin{array}{l}\text { Hawari et } \\
\text { al. }^{39}\end{array}$ & Cross-sectional & $\begin{array}{l}\mathrm{N}=138 \text { (69 WPS and } 69 \text { C); } \\
\text { all participants } 18-26 \text { years } \\
\text { (mean } 22.1 \text { years in WPS } \\
\text { group and } 21.4 \text { years in C } \\
\text { group); } 100 \% \text { males; Jordan }\end{array}$
\end{tabular}

Hawari et

al. ${ }^{42}$

2019

Husain et

al. ${ }^{37}$

2016

Martinasek

et al. ${ }^{5}$

2013

Cross-sectional N=738 (135 WPS, 303 CS, $300 \mathrm{C}) ; 18-27$ years $(21.5 \pm 1.8$
for WPS, $21.7 \pm 1.9$ for $\mathrm{CS}$, for WPS, $21.7 \pm 1.9$ for $C S$,
$21.6 \pm 1.9$ for $\mathrm{C}): 100 \%$ male college campuses in Egypt, Jordan, Morocco, Oman

Cross-sectional N=525 (52 WPS, 69 CS, 122 WPS + CS, $282 \mathrm{C}) ; 16-32$ years $(20.7 \pm 2.1) ; 100 \%$

male; multiple universities in Kuwait White, 5.3\% Black, 27.2\%

Hispanic, 10.4\% Others); all expiratory flow rate - PEFR)

$\mathrm{N}=36578$ (4905 WPS - 57.1\% WP Smoking

participants 9 th-12th grade:

$51.6 \%$ male; Florida
Lung function (peak

WP smoking, Respiratory symptoms WP duration, WP frequency

WP smoking; Cardiorespiratory health WP frequency

Self-reported asthma
Prevalence rate of respiratory symptoms - WPS $=1.6 x$ of $C$ and $C=1.9 x$ of $C$; WPS or $\mathrm{CS}>\mathrm{C}$ for prevalence rate of cough or phlegm.

Persistent cough, chest pain, rapid heart rate - WPS $<$ CS but not different from $C$. No significant difference for respiratory

infections, shortness of breath, high BP,

increase blood sugar levels, sleep disturbances.

PEFR - WPS or CS $>$ C, WP $>$ CS but not statistically significant.

Higher prevalence of ever and current WP users among lifetime and current asthmatics $(p<0.05)$
Methodological information

Self-reported exposure; convenience

sample used; relatively small sample size; excluded participants based on BMI, active chronic medical conditions, chronic prescription medications use, illicit drug use, cardiovascular health measures, oxygen saturation; controlled for factors influencing exercise duration in analysis.

Self-reported exposure; self-reported outcome; convenience sample; controlled for environmental exposures, BMI, physica activities, excluded persons with chronic diseases.

Self-reported exposure only; convenience sample used, no control for confounding.

Descriptive statistics, no control for confounders, self-reported WP smoking and outcome. 
Table 2. Continued

\begin{tabular}{|c|c|c|c|c|c|c|}
\hline $\begin{array}{l}\text { Authors } \\
\text { Year }\end{array}$ & Study design & $\begin{array}{l}\text { Study participant } \\
\text { characteristics }\end{array}$ & $\begin{array}{l}\text { Exposure } \\
\text { measures }\end{array}$ & Outcomes of interest & Key results & Methodological information \\
\hline $\begin{array}{l}\text { Meo et al. }{ }^{34} \\
2014\end{array}$ & Cross-sectional & $\begin{array}{l}\mathrm{N}=146 \text { ( } 73 \text { WPS and } 73 \\
\mathrm{C}) ; \text { mean age }-21.54 \pm 0.41 \\
\text { years in WPS group and } \\
21.36 \pm 0.19 \text { in C; } 100 \% \text { male; } \\
\text { Riyadh, Saudi Arabia }\end{array}$ & WP smoking & $\begin{array}{l}\text { Lung function (via } \\
\text { spirometry) } \\
\text { Respiratory inflammation } \\
\text { (Fractional Exhaled Nitric } \\
\text { Oxide [FENO] concentration) }\end{array}$ & $\begin{array}{l}\text { WPS }<\mathrm{C} \text { for lung function parameters } \\
\text { (FEV1, FEV1/FVC ratio, FEF-25\%, FEF-50\%, } \\
\text { FEF-75\% and FEF-75-85\%. } \\
\text { WPS }<\mathrm{C} \text { for FENO. }\end{array}$ & $\begin{array}{l}\text { Self-reported exposure; convenience sample; } \\
\text { excluded persons with chronic systemic } \\
\text { diseases, substance users, tobacco smokers } \\
\text { (other than WP), regular vigorous exercise, } \\
\text { potential confounding occupational } \\
\text { exposure; age, height, and weight were } \\
\text { similar between groups; did not control for } \\
\text { confounding otherwise. }\end{array}$ \\
\hline $\begin{array}{l}\text { Strulovici- } \\
\text { Barel et al. } \\
2016\end{array}$ & Cross-sectional & $\begin{array}{l}\mathrm{N}=40 \text { participants ( } 19 \text { non- } \\
\text { smoker } \mathrm{C} \text { and } 21 \text { WPS); all } \\
\text { participants } \geq 18 \text { years (mean } \\
33 \pm 9 \text { years in } C \text { group and } \\
25 \pm 4 \text { years in WPS group); } \\
90 \% \text { male in } C, 65 \% \text { male } \\
\text { in WPS group; } 6 / 5 / 8 \text { black/ } \\
\text { white/other in C group and } \\
8 / 2 / 11 \text { black/white/other in } \\
\text { WPS group; New York City, } \\
\text { USA }\end{array}$ & WPS smoking & $\begin{array}{l}\text { Respiratory symptoms } \\
\text { Metabolomic profile of } \\
\text { respiratory tract epithelial } \\
\text { lining fluid } \\
\text { Cellular composition in small } \\
\text { airway epithelium (SAE) } \\
\text { Transcriptome of SAE and } \\
\text { alveolar macrophages (AM) }\end{array}$ & $\begin{array}{l}\text { WPS > C for cough and sputum scores. } \\
31 \text { (out of 1675) features with } \\
\text { significantly different abundance in WPS } \\
\text { vs C. } \\
\text { WPS > C for secretory cells; WPS < C for } \\
\text { basal and ciliated cells. } \\
159 \text { differentially expressed genes in SAE, } \\
181 \text { differentially expressed in AM in WPS } \\
\text { vs C; WPS > C for transcriptome response } \\
\text { score for both SAE and AM. }\end{array}$ & $\begin{array}{l}\text { Self-reported exposure verified with cotinine } \\
\text { and nicotine measurements; convenience } \\
\text { sample used; no confounder control but } \\
\text { study participants in C group and WPS } \\
\text { group were comparable in terms of sex, } \\
\text { ethnicity, body mass index, and alpha-1 } \\
\text { antitrypsin levels. }\end{array}$ \\
\hline
\end{tabular}


Table 2. Continued

\begin{tabular}{|c|c|c|c|c|c|c|}
\hline $\begin{array}{l}\text { Authors } \\
\text { Year }\end{array}$ & Study design & $\begin{array}{l}\text { Study participant } \\
\text { characteristics }\end{array}$ & $\begin{array}{l}\text { Exposure } \\
\text { measures }\end{array}$ & Outcomes of interest & Key results & Methodological information \\
\hline $\begin{array}{l}\text { Tamim et } \\
\text { al. }^{43} \\
2003\end{array}$ & Cross-sectional & $\begin{array}{l}\mathrm{N}=625(53 \text { WPS, } 270 \mathrm{CS} ; 115 \\
\text { WPS + CS, } 187 \mathrm{C}) ; 10-15 \\
\text { years; } 51.6 \% \text { male; Beirut, } \\
\text { Lebanon }\end{array}$ & $\begin{array}{l}\text { WP smoking } \\
\text { by adult } \\
\text { household } \\
\text { member }\end{array}$ & Respiratory symptoms & $\begin{array}{l}\text { OR }(\mathrm{Cl}) \text { : wheezing or nasal congestion for } \\
\text { WPS - } 2.3(1.1-5.1) \text {, wheezing or nasal } \\
\text { congestion for WPS + CS }-3.0(1.7-5.6) \text {, } \\
\text { wheezing for WPS + CS }-4.9(2.3-10.7) \text {, } \\
\text { nasal congestion for WPS + CS }-2.3 \\
(1.1-4.8) \text { compared to C. }\end{array}$ & $\begin{array}{l}\text { Self-reported (presence/absence) exposure } \\
\text { only; participant selection process } \\
\text { unspecified; no control for confounding. }\end{array}$ \\
\hline $\begin{array}{l}\text { Walters et } \\
\text { al. }{ }^{32} \\
2017\end{array}$ & Cross-sectional & $\begin{array}{l}\mathrm{N}=14(7 \mathrm{WPS}, 7 \mathrm{C}) ; 27 \pm 9 \\
\text { years for WPS, } 30 \pm 4 \text { years } \\
\text { for } \mathrm{C} ; 3 \text { males in each } \\
\text { group; black/white/other } \\
\text { distribution }-3 / 0 / 4 \text { for WPS, } \\
3 / 1 / 3 \text { for } \mathrm{C} \text {; New York, USA }\end{array}$ & $\begin{array}{l}\text { 'Light' WP } \\
\text { smoking ( }<5 \\
\text { sessions/week) }\end{array}$ & $\begin{array}{l}\text { Epigenetic and } \\
\text { transcriptomic changes in } \\
\text { small airway epithelial cells }\end{array}$ & $\begin{array}{l}\text { PCA of all DNA methylation probe } \\
\text { sets showed separation of samples by } \\
\text { WP smoking status; } 727 \text { differentially } \\
\text { methylated probe sets ( }>1.5 \text {-fold change) } \\
\text { representing } 673 \text { genes; } 11.3 \% \text { of these } \\
\text { had significant change in gene expression. }\end{array}$ & $\begin{array}{l}\text { Details about sample selection limited } \\
\text { and small sample size; included healthy } \\
\text { subjects (defined on basis of physical exams, } \\
\text { physiological and biochemical parameters, } \\
\text { and medical history); age, gender, ethnicity } \\
\text { and region of SAE controlled for in PCA. }\end{array}$ \\
\hline $\begin{array}{l}\text { Yalcin et al. }{ }^{36} \\
2017\end{array}$ & $\begin{array}{l}\text { Cross-sectional, } \\
\text { pre-post }\end{array}$ & $\begin{array}{l}\mathrm{N}=100(50 \text { WPS/WPS }+ \\
\mathrm{CS} \text { and } 50 \mathrm{C}) 18-38 \text { years } \\
(26.72 \pm 5.2 \text { years for WPS, } \\
27.46 \pm 5.3 \text { years for } \mathrm{C}) ; 66 \% \\
\text { male for WPS, } 64 \% \text { male for } \\
C_{;} \text {Ankara, Turkey }\end{array}$ & $\begin{array}{l}\text { WP smoking; } \\
\text { WP duration; } \\
\text { exhaled CO }\end{array}$ & Lung function (spirometry) & $\begin{array}{l}\text { FVC } \% \text { and FEV } 1 \%(\text { WPS }+ \text { CS }<\text { WPS, C); } \\
\text { FEV1/FVC }(\text { WPS }+ \text { CS }<\text { C); FVC } \% \text {, FEV1\%, } \\
\text { FEV1/FVC, FEF25-75 reduced after WP } \\
\text { smoking. }\end{array}$ & $\begin{array}{l}\text { Controlled WP smoking session; objective } \\
\text { exhaled CO used to quantify exposure but } \\
\text { association with outcome not analyzed; } \\
\text { convenience sample used; no control for } \\
\text { confounding. }\end{array}$ \\
\hline
\end{tabular}

*WPS: waterpipe smokers. CS: cigarette smokers. C: control. 
of the differentially methylated genes between the WP users compared to the non-smokers. Differential expressions in 159 and 181 genes in SAE and alveolar macrophage (AM), respectively, were associated with WP smoking (light users) in another study that was conducted by the same research group.

While there was some overlap between WP and cigarette smokers in the cellular pathways that were affected by differential methylation (xenobiotic metabolism, and aryl hydrocarbon and G-coupled receptor signaling), other impacted pathways were unique to WP smokers ${ }^{32}$. Additionally, there was a predominance of hypermethylation in affected genes in SAE among WP smokers compared to nonsmokers, whereas hypomethylation was predominant in cigarette smokers ${ }^{32,33}$. There was also little overlap in the differentially expressed genes in SAE between WP and cigarette smokers relative to non-smokers. These observations suggest differences in pulmonary pathology that is potentially driven by the differences in the emission contents of tobacco combustion between WP and cigarette smoking.

Similar to cigarette smokers, the composition of recovered SAE cells was altered in young adult WP smokers when compared with non-smokers ${ }^{33}$. However, the pattern of the alteration was different between the two smoking groups. While there was an increased proportion of secretory cells and a decreased proportion of ciliated cells in recovered SAE cells in both groups compared to non-smokers, WP smokers, unlike cigarette smokers, had an increased proportion of basal cells that are the progenitor cells in the airway epithelium ${ }^{33}$.

\section{Effects on pulmonary physiology}

Meo et al. ${ }^{34}$ observed a significant decrease in fractional exhaled nitric oxide (FENO) among young adult WP smokers compared to non-smokers. This result indicates the potential oxidative effect of WP smoking in the respiratory airways, possibly partly due to the conversion of nitric oxide to peroxynitrite by reactive oxygen and nitrogen species released in WP smoke $^{34}$. It also suggests that WP smoking can impair nitric oxide physiological function in regulating both pulmonary function and its bronchodilatory effect which plays an important role in homeostasis and disease $^{35}$. A few studies have reported an effect of WP smoking on pulmonary or lung function among adolescents and young adults ${ }^{33,34,36-38}$. Meo et al. ${ }^{34}$ reported lower values for various spirometry measures including forced expiratory volume in one second $\left(\mathrm{FEV}_{1}\right)$, its ratio $\left(\mathrm{FEV}_{1} / \mathrm{FVC}\right)$ to forced vital capacity (FVC), and forced expiratory flows (FEFs) at different percentages $(25,50,75$, and $75-85 \%)$ of FVC among WP smokers compared to non-smoking young adults. Additionally, peak expiratory flow (PEF) was lower among young tobacco smoking adults ${ }^{37}$. Although, the types of tobacco smoking were not differentiated in the comparison with non-smokers in the study, PEF was lower (insignificantly) among persons who exclusively smoked WP compared to those who exclusively smoked cigarettes ${ }^{37}$. Lower percentages of predicted spirometry values, especially for FVC, $\mathrm{FEV}_{1}$, and PEF, were similarly observed among young adult WP smokers vs non-smokers ${ }^{33,36,39}$. These findings suggest that WP smoking could contribute to obstructive and restrictive lung pathologies and the development of chronic pulmonary disease $\mathrm{e}^{40,41}$. Furthermore, acute decline in lung function following WP smoking has been demonstrated ${ }^{36,38}$, and this was accompanied by increased breathing rate in one of the studies ${ }^{38}$.

Respiratory symptoms, lung injury, lung infection, and lung disease

WP smoke exposure was consistently associated with increased risk of respiratory symptoms across studies ${ }^{39,42,43}$. In a cross-sectional study, Hawari et al. ${ }^{39}$ reported that a significantly higher proportion of young adult WP smokers, compared with non-smoking controls, self-reported any respiratory symptom (72.5\% vs $21.7 \%)$, chest illness that prevented them from working within the previous three years $(25.0 \%$ vs $10.1 \%$ ), and coughing up phlegm lasting more than three weeks ( $11.6 \%$ vs $0.0 \%)$. In another study that was conducted across multiple Middle Eastern countries, the same research group observed that college student WP smokers were $60 \%$ more likely to report respiratory symptoms, e.g. cough and phlegm, compared to non-smokers ${ }^{42}$. There was no difference in the risk for these outcomes compared to cigarette smokers in both studies. Relative to secondhand smoke exposure, elementary school children who lived at home with at least one person who smoked WP and/or cigarettes, compared with children who did not, had increased incidence of wheezing and/or nasal 
congestion within the previous year ${ }^{43}$. Consistent with the evidence indicating increased risk of respiratory symptoms, cases of acute lung injury (granulomatous lesions and pneumomediastinum $)^{44,45}$, pulmonary eosinophilic inflammation ${ }^{46,47}$, and pulmonary infection (mycobacterium tuberculosis and burkholderia pseudomallei $)^{48,49}$ following WP smoking activities have been reported in young adult individuals. However, there was no apparent increase in the risk of respiratory symptoms among WP smoking young adults compared to non-smokers in another study ${ }^{37}$. Finally, higher prevalence or odds of WP smoking was observed among persons with asthma in crosssectional surveys of 9th to12th graders in Florida ${ }^{50,51}$.

\section{Comments about studies of pulmonary effects}

All but one (a cross-over study) of the studies of pulmonary effects of WP smoking in adolescents and/or young adults were case studies, pre-post, or cross-sectional studies. Most (66\%) of the 15 studies were conducted in the Middle East. Also, most relied on self-reported smoking information, and did not control for potential confounders. Whereas some of the studies included both male and female participants, none of the studies tested gender effects and none provided dose-response information.

\section{Cardiovascular effects}

WP smoke is associated with adverse cardiovascular outcomes ${ }^{16}$. Several studies have reported that WP smoking induces hemodynamic and vascular responses, and impairs cardiac autonomic control in adolescents and young adults (Table 3 ).

\section{Hemodynamic effects}

The acute vascular response to WP smoking among young adults reflects the differential effects of tobacco smoke components in different tissue beds. In one study, calf muscle blood flow and vascular resistance measured by venous occlusion straingauge plethysmography increased and decreased, respectively, in young adults following WP smoking ${ }^{52}$. Similarly, Nelson et al. ${ }^{53}$ observed an increase in myocardial blood flow and conductance in young adults following WP smoking. In contrast, blood flow decreased and vascular resistance increased in the forearm and foot skin following WP smoking ${ }^{52,54,55}$. These differential effects are the consequence of the dilatory effect of nicotine in skeletal muscles and coronary vessels versus its constrictive effect in cutaneous vessels ${ }^{52,53}$. Carbon monoxide, another major component of WP tobacco smoke, also has a dilatory effect in the skeletal muscle beds and coronary vessels, but not in the skin $^{52,53}$.

Also, evidence in the literature suggests opposite directionality for the effects of acute and chronic WP smoking on blood pressure. Although, diastolic blood pressure (DBP), systolic blood pressure (SBP) and heart rate (HR) did not change across work shifts among WP bar workers exposed to secondhand smoke $^{56}$, observations about increases in these measures and mean arterial pressure (MAP) among young adults following WP smoking are consistent across studies ${ }^{52-54,57-60}$. Al-Safi et al. ${ }^{61}$ also reported higher SBP, DBP, MAP and HR in young adult WP smokers compared to non-smokers in a large population-based study ( $\mathrm{n}=7845)$, while WP smoking was not associated with the prevalence of high BP among young adults in another study ${ }^{37}$. However, results in other studies suggest an opposite chronic effect among adolescents with WP smoking-associated decreases in BP being observed only among boys in one of the studies ${ }^{62,63}$. The apparent opposed directions in the BP effect of acute (increased BP) and chronic (decreased BP) WP smoke exposure is similar to what has been reported for cigarette smoke ${ }^{64-71}$. Alomari et al. ${ }^{64}$ observed reduced BP among WP smoking adolescents compared to non-smoking controls.

Although the basis for the seeming dichotomy in $\mathrm{BP}$ effects has not been clarified, the intermittent stimulation of the sympathetic nervous system, that is causal for vasoconstriction and increased hemodynamic activity, by repeated exposure to nicotine from tobacco smoking, and subsequent 'overcompensation' of the body and excessive vasodilation in the absence of nicotine during non-smoking periods have been hypothesized as a potential mechanism ${ }^{62-64}$. It is important to note that reduced BP is not necessarily beneficial or harmless as it could be a risk factor for cardiovascular (especially coronary) events $^{62,72-75}$.

Impairment of vascular function and other cardiovascular effects

WP smoking impairs vascular function in young adults ${ }^{58,59,76}$. A 30-minute smoking session of a 
Table 3. Studies of cardiovascular effects of WP smoking in adolescents and young adults

\begin{tabular}{|c|c|c|c|c|c|}
\hline $\begin{array}{l}\text { Authors } \\
\text { Year }\end{array}$ & Study design & $\begin{array}{l}\text { Study participant } \\
\text { characteristics }\end{array}$ & $\begin{array}{l}\text { Exposure } \\
\text { measures }\end{array}$ & Outcomes of interest & Key results \\
\hline $\begin{array}{l}\text { Ahmadian et } \\
\text { al. }^{84} \\
2017\end{array}$ & Cross-sectional & $\begin{array}{l}\mathrm{N}=20(10 \text { WPS, } 10 \mathrm{C}) \text { age } \\
>20 \text { years }(27.6 \pm 3.1 \text { for } \\
\text { WPS, } 26.1 \pm 3.6 \text { for } \mathrm{C}) ; 100 \% \\
\text { sedentary male; Aliabad Katoul, } \\
\text { Iran }\end{array}$ & WP Smoking & Hematological parameters & $\begin{array}{l}\text { WPS > C for hematological variables } \\
\text { (white blood cells, hematocrit, } \\
\text { lymphocytes, neutrophils). }\end{array}$ \\
\hline $\begin{array}{l}\text { Alomari et } \\
\text { al. }^{62} \\
2018\end{array}$ & Cross-sectional & $\begin{array}{l}\mathrm{N}=397(161 \text { WPS, } 236 \mathrm{C}) ; \\
14.5 \pm 1.1 \text { years for both WPS } \\
\text { and } \mathrm{C} ; 59.6 \% \text { male WPS, } 54.6 \% \\
\text { male } \mathrm{C} . \text { Irbid, Jordan }\end{array}$ & $\begin{array}{l}\text { WP smoking; } \\
\text { WP frequency }\end{array}$ & Hemodynamics & $\begin{array}{l}\text { Heart rate, } \mathrm{DBP} \text {, mean arterial } \mathrm{BP} \text {, and } \\
\text { rate pressure product }(\mathrm{WPS}<\mathrm{C} \text { ). }\end{array}$ \\
\hline $\begin{array}{l}\text { Alomari et } \\
\text { al. }^{63} \\
2020\end{array}$ & Cross-sectional & 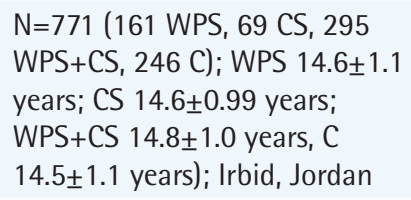 & $\begin{array}{l}\text { WP smoking, } \\
\text { WP frequency }\end{array}$ & Hemodynamics & $\begin{array}{l}\text { WPS, CS }<\text { C for heart rate, DBP, } \\
\text { mean arterial BP, and rate pressure } \\
\text { product. Results not different when } \\
\text { stratified by gender. }\end{array}$ \\
\hline $\begin{array}{l}\text { Hawari et } \\
\text { al. }^{39} \\
2017\end{array}$ & Cross-sectional & $\begin{array}{l}\mathrm{N}=138 \text { ( } 69 \text { WPS and } 69 \mathrm{C} \text { ); all } \\
\text { participants } 18-26 \text { years (mean } \\
22.1 \text { years in WPS group and } \\
21.4 \text { years in } \mathrm{C} \text { group); } 100 \% \\
\text { males; Jordan }\end{array}$ & WPS smoking & $\begin{array}{l}\text { Cardiopulmonary exercise } \\
\text { test }\end{array}$ & $\begin{array}{l}\text { WPS }<\mathrm{C} \text { for } \mathrm{VO} 2 \mathrm{~mL} / \mathrm{kg} \text { and } \mathrm{HR} \\
\text { at peak exercise, change in EELV, } \\
\mathrm{HRR}, \text { Pet } \mathrm{CO} 2 \text {, and VE/VCO2; WPS } \\
>\mathrm{C} \text { for shortness of breath and leg } \\
\text { fatigue at mid exercise; WPS }<\mathrm{C} \text { for } \\
\text { exercise time in both bivariate and } \\
\text { multivariate analyses. }\end{array}$ \\
\hline $\begin{array}{l}\text { Selim et al. }{ }^{76} \\
2013\end{array}$ & Cross-sectional & $\begin{array}{l}\mathrm{N}=70(30 \text { WPS, } 30 \mathrm{CS}, 10 \mathrm{C}) \\
25-35 \text { years }(28 \pm 3 \text { years for } \\
\text { WPS, } 29 \pm 3 \text { for CS and } 30 \pm 3.6 \\
\text { for } \mathrm{C}) ; 100 \% \text { male; Cairo, Egypt }\end{array}$ & $\begin{array}{l}\text { WP Smoking, } \\
\text { WP frequency } \\
\text { and duration }\end{array}$ & Vascular function & $\begin{array}{l}\text { Flow mediated dilation (FMD\%) } \\
\text { - WPS }<\text { CS }<\text { C; FMD\% reduced } \\
\text { with increasing duration (year) and } \\
\text { frequency per day of WP and for } \\
\text { indoor vs outdoor WP smoking. }\end{array}$ \\
\hline
\end{tabular}

\section{Methodological information}

Self-reported exposure to WP; participant selection process unspecified, no control for confounding.

sedentary male: Aliabad Katou,

ample used; excluded students With hy glycemia, tension, lipidemia, choleterolemia; mood disorders, medication that can alter cardiovascular function.

Self-reported exposure; convenience sample used; control for confounding including BMI, height, and gender

Self-reported exposure only, exclusivity of WP or cigarette smoking; convenience sample used; excluded individuals with previously cardiovascular disease.

Self-reported exposure; convenience sample used; relatively small sample size; excluded participants based on BMI, active chronic medical conditions, chronic prescription medications use, illicit drug use, cardiovascular health measures, oxygen saturation; controlled for factors influencing exercise duration in analysis.

Self-reported exposure only; convenience sample used; excluded combined smokers, persons with cardiovascular disease, or taking medication affecting vasomotor function. 
Table 3. Continued

\begin{tabular}{|c|c|c|c|c|c|c|}
\hline $\begin{array}{l}\text { Authors } \\
\text { Year }\end{array}$ & Study design & $\begin{array}{l}\text { Study participant } \\
\text { characteristics }\end{array}$ & $\begin{array}{l}\text { Exposure } \\
\text { measures }\end{array}$ & Outcomes of interest & Key results & Methodological information \\
\hline $\begin{array}{l}\text { Alomari et } \\
\text { al. }^{54} \\
2014\end{array}$ & Pre-post & $\begin{array}{l}\mathrm{N}=53 \text { (53 WPS) } 18-35 \text { years } \\
\text { (mean: } 22.7 \pm 4.8 \text { ); gender } \\
\text { unspecified; Irbid, Jordan }\end{array}$ & $\begin{array}{l}\text { WP smoking } \\
\text { session }\end{array}$ & Hemodynamics & $\begin{array}{l}\text { WPS session increased heart rate, } \\
\text { DBP, mean arterial BP, rate pressure } \\
\text { product, and post-occlusion vascular } \\
\text { resistance. Post-occlusion blood }\end{array}$ & $\begin{array}{l}\text { Controlled WP smoking session; participant } \\
\text { selection process unspecified; excluded } \\
\text { persons with acute medical conditions, } \\
\text { cardiovascular, kidney, or metabolic disease, c }\end{array}$ \\
\hline
\end{tabular}

$\begin{array}{llll}\text { Alomari et } & \text { Pre-post } & \text { N=53 (53 WPS) } 18-36 \text { years } & \text { WP smoking Hemodynamics } \\ \text { al. }{ }^{55} & & (22.7 \pm 4.8) ; 64 \% \text { male; Irbid, } & \text { session } \\ 2015 & & \text { Jordan }\end{array}$

Cobb et al. ${ }^{60}$ Pre-post 2012

$\mathrm{N}=32$ WPS; $21.6 \pm 2.7$ years $50 \%$ male; $68.9 \%$ Non-White; session Richmond, VA, US
$\mathrm{N}=61$ (61 WPS) 18-25 years; WP smoking Hemodynamics 80\% male; London, UK

session

WP smoking Hemodynamics

$\mathrm{N}=28$ WPS;

$27 \pm 1$ years; $71.4 \%$ male; $32.1 \%$ session

Non-Hispanic White, 50\%

Non-Hispanic Black، 17.9\%

Other; US
Autonomic cardiac control (frequency domain)

Heart rate variability measures - low frequency power and its ratio to high frequency power increased, sample entropy decreased immediately after smoking WP with tobacco but not tobacco-free WP.

DBP, SBP, mean arterial BP and heart rate increased post-smoking; change across WP smoking session not associated with $\mathrm{CO}$.

DBP, SBP, and mean arterial blood pressures, and heart rate increased significantly after WP smoking.

Myocardial blood flow

Myocardial blood flow velocity, blood flow and venous outflow decreased afterwards.

WPS session slightly decreased

forearm post-occlusion blood flow, increased post occlusion vascular resistance, and decreased post occlusion venous outflow.

Heart rate (immediately after), DBP (immediately and 15 mins after), and SBP (15 mins after) increased

following smoking WP with tobacco but not tobacco-free WP.

those using medications with cardiovascu effect.

Controlled WP smoking session; exclusion based on chronic diseases, regular use of prescription medication, pregnancy or breast feeding, cigarette smoking.

Required abstinence from WP smoking confirmed objectively; convenience sample; inclusion based on number of tobacco

products smoked, objective cardiopulmonary measures, chronic diseases, pregnancy status. flow, and conductance (1.1-1.5 au/ $\mathrm{mmHg}$ ) increased after WP smoking. 
Table 3. Continued

\begin{tabular}{|c|c|c|c|c|c|c|}
\hline $\begin{array}{l}\text { Authors } \\
\text { Year }\end{array}$ & Study design & $\begin{array}{l}\text { Study participant } \\
\text { characteristics }\end{array}$ & $\begin{array}{l}\text { Exposure } \\
\text { measures }\end{array}$ & Outcomes of interest & Key results & Methodological information \\
\hline $\begin{array}{l}\text { Rezk-Hanna } \\
\text { et al. }{ }^{58} \\
2018\end{array}$ & Pre-post & $\begin{array}{l}\mathrm{N}=48 \text { (48 WPS) } 18-34 \text { years } \\
(25 \pm 4) ; 65 \% \text { male; Los Angeles, } \\
\mathrm{CA}\end{array}$ & $\begin{array}{l}\text { WP smoking } \\
\text { session }\end{array}$ & Hemodynamics & $\begin{array}{l}\text { Central arterial stiffness } \\
\text { (augmentation index) and carotid- } \\
\text { femoral pulse wave velocity increased } \\
\text { post WP; no gender differences. } \\
\text { After smoking, increase in heart } \\
\text { rate, respiratory rate, brachial artery } \\
\text { and aortic DBP and SBP; no gender } \\
\text { differences. }\end{array}$ & $\begin{array}{l}\text { Controlled WP smoking session with } \\
\text { objectively measured exposure exhaled co } \\
\text { and plasma nicotine; convenience sample } \\
\text { used; exclusion based on chronic systemic } \\
\text { disease, drug use, physical evidence of } \\
\text { cardiopulmonary disease, sinus rhythm, } \\
\text { pregnancy, prescription medication, } \\
\text { antioxidant supplementations, pre-smoking } \\
\text { exhaled CO } \geq 10 \text { ppm, psychiatric illness. }\end{array}$ \\
\hline $\begin{array}{l}\text { Rezk-Hanna } \\
\text { et al. }{ }^{59} \\
2019\end{array}$ & Pre-post & $\begin{array}{l}\mathrm{N}=30 \text { WPS, } 15 \mathrm{CS} ; \\
26 \pm 1 \text { years; } 62.2 \% \text { male; } \\
40 \% \text { Non-Hispanic White, } \\
22.2 \% \text { Non-Hispanic Black, } \\
7 \% \text { Hispanic, } 20 \% \text { Asian, } 11 \% \\
\text { Other; US }\end{array}$ & $\begin{array}{l}\text { WP smoking } \\
\text { session }\end{array}$ & Vascular function & $\begin{array}{l}\text { FMD - changed by }+43 \pm 6 \%,-27 \pm 4 \% \text {, } \\
+138 \pm 71 \%,-36 \pm 4 \% \text { after smoking } \\
\text { charcoal heated WP, electrically } \\
\text { heated WP, } 0.1 \% \text { carbon monoxide, } \\
\text { cigarette. }\end{array}$ & $\begin{array}{l}\text { Required abstinence from WP smoking, } \\
\text { confirmed objectively; convenience sample; } \\
\text { inclusion criteria based on number of tobacco } \\
\text { products smoked, healthy cardiopulmonary } \\
\text { measures, BMI, pregnancy status. }\end{array}$ \\
\hline $\begin{array}{l}\text { Rezk-Hanna } \\
\text { et al. } .^{5} \\
2020\end{array}$ & Pre-post & $\begin{array}{l}\mathrm{N}=21 ; 24 \pm 1 \text { years; } 57 \% \text { male; } \\
38.1 \% \text { Non-Hispanic White, } \\
33.3 \% \text { Non-Hispanic Black, } \\
\text { 19\% Hispanic, } 9.5 \% \text { Other; US }\end{array}$ & $\begin{array}{l}\text { WP smoking } \\
\text { session }\end{array}$ & Hemodynamics & $\begin{array}{l}\text { DBP, SBP, and mean arterial blood } \\
\text { pressures, and heart rate increased } \\
\text { significantly } 30 \text { minutes after WP } \\
\text { smoking } \\
\text { Foot skin blood flow reduced } \\
\text { and vascular resistance increased } \\
\text { respectively, calf muscle blood flow } \\
\text { and vascular resistance increased } \\
\text { and reduced respectively post-flow; } \\
\text { changes sustained until } 30 \text { minutes } \\
\text { after WP smoking. }\end{array}$ & $\begin{array}{l}\text { WP smoking session; required abstinence } \\
\text { from WP smoking, confirmed objectively; } \\
\text { convenience sample; inclusion criteria based } \\
\text { on objective cardiopulmonary measures, BMI, } \\
\text { pregnancy status. }\end{array}$ \\
\hline $\begin{array}{l}\text { Rezk-Hanna } \\
\text { et al. }{ }^{59} \\
2019\end{array}$ & Pre-post & $\begin{array}{l}\mathrm{N}=30 \text { WPS, } 15 \mathrm{CS} ; \\
26 \pm 1 \text { years; } 62.2 \% \text { male; } \\
40 \% \text { Non-Hispanic White, } \\
22.2 \% \text { Non-Hispanic Black, } \\
7 \% \text { Hispanic, } 20 \% \text { Asian, } 11 \% \\
\text { Other; US }\end{array}$ & $\begin{array}{l}\text { WP smoking } \\
\text { session }\end{array}$ & Vascular function & $\begin{array}{l}\text { FMD - changed by }+43 \pm 6 \%,-27 \pm 4 \% \text {, } \\
+138 \pm 71 \%,-36 \pm 4 \% \text { after smoking } \\
\text { charcoal heated WP, electrically } \\
\text { heated WP, } 0.1 \% \text { carbon monoxide, } \\
\text { cigarette. }\end{array}$ & $\begin{array}{l}\text { Required abstinence from WP smoking, } \\
\text { confirmed objectively; convenience sample; } \\
\text { inclusion criteria based on number of tobacco } \\
\text { products smoked, healthy cardiopulmonary } \\
\text { measures, BMI, pregnancy status. }\end{array}$ \\
\hline
\end{tabular}


Table 3. Continued

\begin{tabular}{|c|c|c|c|c|c|c|}
\hline $\begin{array}{l}\text { Authors } \\
\text { Year }\end{array}$ & Study design & $\begin{array}{l}\text { Study participant } \\
\text { characteristics }\end{array}$ & $\begin{array}{l}\text { Exposure } \\
\text { measures }\end{array}$ & Outcomes of interest & Key results & Methodological information \\
\hline $\begin{array}{l}\text { Yildirim et } \\
\text { al. }^{77} \\
2016\end{array}$ & Pre-post & $\begin{array}{l}\mathrm{N}=33(33 \mathrm{WPS}) ; \\
26.8 \pm 6.2 \text { years; } 84.8 \% \text { male }\end{array}$ & $\begin{array}{l}\text { WP smoking } \\
\text { session }\end{array}$ & $\begin{array}{l}\text { Electrocardiogram, } \\
\text { hemodynamics }\end{array}$ & $\begin{array}{l}\text { DBP, SBP increased; oxygen } \\
\text { saturation decreased; dispersions of } \\
\text { OT, QTc, P-wave and Tp-Te increased } \\
\text { after WP smoking. }\end{array}$ & $\begin{array}{l}\text { Self-reported WPS; convenience sample; } \\
\text { excluded persons aged }<18 \text { years, } \\
\text { cardiovascular morbidity/medication. }\end{array}$ \\
\hline $\begin{array}{l}\text { Zhou et al. }{ }^{56} \\
2017\end{array}$ & Pre-post & $\begin{array}{l}\mathrm{N}=10 \text { (hookah bar workers); } \\
\geq 20 \text { years (mean: } 26.6 \pm 2.8) ; \\
20 \% \text { male; NYC (Manhattan), } \\
\text { NY }\end{array}$ & $\begin{array}{l}\text { Air quality of } \\
\text { hookah bar } \\
\text { exhaled CO, } \\
\text { saliva cotinine }\end{array}$ & Hemodynamics & $\begin{array}{l}\text { Non-statistically significant increase } \\
\text { in heart rate, SBP, and DBP across } \\
\text { work shift. }\end{array}$ & $\begin{array}{l}\text { Objective exposure measured by air sampling } \\
\text { and biomarkers; convenience sample used; } \\
\text { inclusion limited to people aged } \geq 20 \text { years, } \\
\text { working in hookah bar, and exclusion of } \\
\text { pregnant women, current CS; small sample } \\
\text { size. }\end{array}$ \\
\hline
\end{tabular}

*WPS: waterpipe smokers. CS: cigarette smokers. C: control. 
standard charcoal-heated WP increased central arterial stiffness as indicated by increased pulse wave velocity and augmentation inde $\mathrm{x}^{58}$. However, charcoal-heated WP smoking in another study induced a contrary effect on endothelial function with flow-mediated dilation (FMD) increasing after smoking ${ }^{59}$. This was attributed to the high content of vasodilatory $\mathrm{CO}$ in smoke from the combustion of the charcoal. In the study, inhalation of a $\mathrm{CO}$ gas mixture that achieved a similar $\mathrm{CO}$ boost as the smoking of the charcoal-heated WP caused a larger increase in FMD. In contrast, FMD decreased after the smoking of an electronically heated WP. Therefore, it was concluded that $\mathrm{CO}$ masks the induction of endothelial dysfunction by other components of WP smoke including nicotine and particulates. The authors of the study hypothesized that this attenuating effect is temporary and that FMD will eventually decrease following $\mathrm{CO}$ clearance from circulation ${ }^{59}$. Indeed, Selim et al. ${ }^{76}$ reported that FMD was reduced 0.66x and $0.37 \mathrm{x}$ in WP smoking young adults compared to cigarette smoking and non-smoking controls, with an inverse relationships between FMD and the number of WP smoking session per day.

Furthermore, the impairment of cardiac autonomic control, which is associated with adverse cardiovascular events, is observed following WP smoking in young adults ${ }^{60,77}$. Also, Hawari et al..$^{39}$ observed that exercise performance, as indicated by components of the cardiopulmonary exercise test (CPET), was impaired among young adult WP smokers compared to nonsmokers. Heart rate, perceived exertion (Borg scale), and self-reported leg fatigue were increased, and peak oxygen consumption and exercise time were reduced among the smokers.

\section{Comments about studies of cardiovascular effects}

All 19 studies of the cardiovascular effect of WP smoking among adolescents and young adults that were identified were either cross-sectional or prepost in design. Thirteen studies reported on acute effects; twelve studies were conducted in the Middle East, six in the United States, and one in the United Kingdom. Most of the studies controlled for potential confounders by using them as selection criteria of the study. Although only six of the studies were exclusively composed of male participants, or did not report gender distribution, just one study reported on testing for gender differences. Finally, dose-response association was reported by only one of the studies.

\section{Neurological and psychological effects}

In general, tobacco use is linked with the impairment of mental health. However, the etiology and the directionality of the association is not clear ${ }^{78-80}$. Depression, for example, could predispose a person towards tobacco smoking ${ }^{78-80}$. On the other hand, smoking might be a cause of depression ${ }^{78-80}$. A third alternative is that there is not a causal link between the two, and that they both occur due to common risk factors $^{79}$. Nonetheless, there are few studies (Table 4) about the association between WP smoking and mental health disorders among adolescents and young adults, but the results of the studies are inconsistent.

\section{Psychological effects}

No association was observed for depressive symptoms, anxiety, or stress, in three studies of college students ${ }^{78,81,82}$. In contrast, the odds of past 30 -day WP smoking increased by $30-140 \%$ with self-reported mental health diagnosis (including depression, anxiety, sleeping disorder, attentiondeficit disorder, and addictive disorder) in a national survey of college students ${ }^{80}$. The odds of current use of WP was also associated with a psychological stress scale (on Cohen's Perceived Stress Scale) and a depression scale (the Center for Epidemiologic Studies Depression Iowa Short Form) but not with self-reported mental health diagnosis in another study of college students ${ }^{83}$. Marsden et al. ${ }^{79}$ observed that the score on the Center for Epidemiologic Studies Depression 10 Scale increased by $3 \%$ with every 5 -day increase in usage in the past 30 days in their study. Also, the score increased by $4 \%$ and $9 \%$ for at least 5 days and 15 days of usage in the past 30 days, respectively, among college students ${ }^{79}$. Unlike the other studies, the results from the Marsden et al. ${ }^{84-86}$ study were based on longitudinally collected and repeated measures data with some information about directionality. They were also able to adjust for the use of other tobacco products in their analyses.

\section{Neurocognitive effects}

A few studies have examined the association between WP smoking and cognitive function in young adults. There was no difference in the assessed cognitive 
Table 4. Studies of neurological and psychological effects of WP smoking in adolescents and young adults

\begin{tabular}{|c|c|c|c|c|c|c|}
\hline $\begin{array}{l}\text { Authors } \\
\text { Year }\end{array}$ & Study design & Study participant characteristics & $\begin{array}{l}\text { Exposure } \\
\text { measures }\end{array}$ & Outcomes of interest & Key results & Methodological information \\
\hline $\begin{array}{l}\text { Marsden et } \\
\text { al. }^{79} \\
2019\end{array}$ & Cohort & $\begin{array}{l}\mathrm{N}=5236 \text { (out of } 5482 \text { ) smokers } \\
(\mathrm{N}=885 \text { smoked WP); } 18-29 \text { years; } \\
36.7 \% \text { male; } 37.3 \% \text { non-Hispanic } \\
\text { white, } 30.9 \% \text { Hispanic, } 16.8 \% \\
\text { Asian, } 7.5 \% \text { Black, } 7.5 \% \text { others; } \\
\text { Texas, US }\end{array}$ & $\begin{array}{l}\text { WP smoking; } \\
\text { WP frequency }\end{array}$ & $\begin{array}{l}\text { Psychological - depression } \\
\text { (CES-D-10) }\end{array}$ & $\begin{array}{l}\text { RR is } 1.03(1.01-1.05) \text { for a } 1 \text {-unit } \\
\text { rise in scaled unit of frequency of } \\
\text { WP smoking; RR is } 1.04(1.01-1.06) \\
\text { and } 1.09 \text { (1.04-1.15) for } 5 \text {-day and } \\
15 \text {-day of use within last } 30 \text { days, } \\
\text { respectively. }\end{array}$ & $\begin{array}{l}\text { Large sample of college students from } \\
\text { multiple recruitment waves with repeated } \\
\text { measurements; information collected at } \\
\text { 6-month intervals; adjustments for age, } \\
\text { ethnicity, sex, educational level, father's } \\
\text { education and wave number. }\end{array}$ \\
\hline Ahmadian et & Cross-sectional & $\mathrm{N}=20$ (10 WPS, $10 \mathrm{C}$ ) age $>20$ & WP Smoking & Cognitive function - number & No significant difference observed & Self-reported exposure to WP; participant \\
\hline
\end{tabular}

al. $^{84}$

2017

Alomari et Cross-sectional

al. $^{87}$

2018

Bandiera et Cross-sectiona

al. $^{78}$

2016

$\mathrm{N}=5438$ students from 24 metropolitan colleges; $18-29$ years; $63.8 \%$ female; $36.3 \%$ non-

Hispanic white, $31.3 \%$ Hispanic

16.9\% Asian, 8.1 non-Hispanic

Black, 7.5\% Other; Texas

Goodwin et Cross-sectional $\quad \mathrm{N}=1799$ college students; $20.1 \pm 1.5$ WP smoking al. ${ }^{81}$

2014 years for WPS, $19.8 \pm 1.4$ for $C$;

$58.8 \%$ female; Northeastern US

Heinz et al. ${ }^{82}$ Cross-sectional $\quad \mathrm{N}=143(48 \%$ ever WPS); 2013
$19.26 \pm 3.42$ years; $24 \%$ male; 360 Caucasian, 7\% African American

19\% Hispanic, 33\% Asian, 5\%

Other; Chicago, US

recall within $30 \mathrm{~s}$ Wingate

supramaximal exercise test

between WPS and C pre- and post-

exercise.

Neurological - biomarker

(brain-derived neurotrophic factor - BDNF)

WP smoking Psychological - depression (CES-D-10)

Psychological - mental health (self-reported

diagnosis/treatment by a physician), perceived stress (self-reported level)

WP smoking, Psychological (depression) WP frequency - Inventory to Diagnose Depression
WP smoking associated with reduced circulating BDNF

$R$ for depressive symptoms is 1.01 (0.85-1.19) for WPS use.

No association with mental health problems; no association with perceived stress.

No difference in depression symptomatology by WP use. selection process unspecified, no control for confounding.

Self-reported exposure; multi-stage random cluster sampling; controlled for $\mathrm{BMI}$, age, gender and location in analysis; individuals self-reporting hyperlipidemia hypercholesterolemia, hypertension, cardiac condition, hyperglycemia, psychiatric and stress-related mood disorders were excluded.

Self-reported exposure to WP; not clear if WP smokers were not multi-product users; large sample of college students from multiple colleges; adjustments for age, ethnicity, gender, college type.

Self-reported exposure; adjustments for age, gender, sorority status.

Self-reported exposure; convenience sample; lack of control for confounders. 
Table 4. Continued

\begin{tabular}{|c|c|c|c|c|c|c|}
\hline $\begin{array}{l}\text { Authors } \\
\text { Year }\end{array}$ & Study design & Study participant characteristics & $\begin{array}{l}\text { Exposure } \\
\text { measures }\end{array}$ & Outcomes of interest & Key results & Methodological information \\
\hline $\begin{array}{l}\text { King et al. } .^{83} \\
2018\end{array}$ & Cross-sectional & $\begin{array}{l}\mathrm{N}=2370 ; 21.1 \pm 0.4 \text { years; } 35.9 \% \\
\text { male; } 83.2 \% \text { White, } 16.8 \% \text { Non- } \\
\text { White; Colleges in VA and NC, US }\end{array}$ & $\begin{array}{l}\text { WP smoking, } \\
\text { WP frequency }\end{array}$ & $\begin{array}{l}\text { Psychological - self-reported } \\
\text { mental health conditions } \\
\text { (depression, anxiety, ADHD), } \\
\text { stress (Cohen's 10-item } \\
\text { Perceived Stress Scale), } \\
\text { depression (CES-D Short } \\
\text { Form) }\end{array}$ & $\begin{array}{l}\text { OR }(\mathrm{Cl}) \text { for WP use }-1.04(1.01-1.06) \\
\text { per increase on Stress Scale Score, } \\
1.03(1.00-1.07) \text { per increase } \\
\text { on Depression Scale Score, no } \\
\text { association with mental health } \\
\text { diagnosis. }\end{array}$ & $\begin{array}{l}\text { Self-reported WP smoking and mental } \\
\text { health diagnoses; survey of college } \\
\text { students, controlled for age, sex, race, } \\
\text { ethnicity, and mother's education and } \\
\text { cigarette smoking. }\end{array}$ \\
\hline $\begin{array}{l}\text { Meo et al. }{ }^{86} \\
2017\end{array}$ & Cross-sectional & $\begin{array}{l}\mathrm{N}=65(33 \text { WPS, } 32 \mathrm{C}) ; 24.45 \pm 2.93 \\
\text { years for WPS, } 23.32 \pm 2.68 \text { years } \\
\text { for C); } 100 \% \text { male; Riyadh, Saudi } \\
\text { Arabia }\end{array}$ & WP smoking & $\begin{array}{l}\text { Neurological - cognitive } \\
\text { function (Cambridge } \\
\text { Neuropsychological } \\
\text { Automated Battery - } \\
\text { CANTAB) }\end{array}$ & $\begin{array}{l}\text { WPS }<\mathrm{C} \text { for attention switching task } \\
\text { (AST) latency, AST congruent, AST } \\
\text { incongruent, mean choice reaction } \\
\text { time (CRT), CRT\%. }\end{array}$ & $\begin{array}{l}\text { Self-reported exposure to WP; groups } \\
\text { matched based on age, gender, ethnicity, } \\
\text { weight, height, SES, education level; } \\
\text { excluded based on chronic morbidity, } \\
\text { substance use and cigarette smoking; } \\
\text { convenience sample with groups apparently } \\
\text { from different populations; WPS not } \\
\text { exclusively WP smoking. }\end{array}$ \\
\hline $\begin{array}{l}\text { Primack et } \\
\text { al. }^{80} \\
2013\end{array}$ & Cross-sectional & $\begin{array}{l}\mathrm{N}=100891 ; \text { about } 92 \% 18-26 \\
\text { years; } 65.7 \% \text { male; } 70.2 \% \text { White, } \\
4.8 \% \text { Black, } 6.1 \% \text { Hispanic, } 9.7 \% \\
\text { Asian, } 9.2 \% \text { Other; Colleges in US }\end{array}$ & $\begin{array}{l}\text { WP smoking, } \\
\text { WP frequency }\end{array}$ & $\begin{array}{l}\text { Psychological - self-reported } \\
\text { mental health conditions } \\
\text { (depression, anxiety, sleep } \\
\text { disorder, ADHD, addictive } \\
\text { disorder, stress) }\end{array}$ & $\begin{array}{l}\text { OR (CI) for WP use - } 1.4(1.3-1.5) \text { if } \\
\text { depressed, } 1.1(1.0-1.2) \text { if stressed. }\end{array}$ & $\begin{array}{l}\text { Self-reported WP smoking and mental } \\
\text { health diagnoses; large national survey; } \\
\text { controlled for gender, sexual orientation, } \\
\text { undergraduate status, race, relationship } \\
\text { status, region, population size, and } \\
\text { clustering by school. }\end{array}$ \\
\hline $\begin{array}{l}\text { Saadat et } \\
\text { al. }^{85} \\
2018\end{array}$ & Pre-post & $\begin{array}{l}\mathrm{N}=22(\text { WPS and } \mathrm{CS}-\text { numbers } \\
\text { not noted); } 18-22 \text { years (mean: } \\
21.4 \pm 0.8) ; 100 \% \text { male; Tehran, Iran }\end{array}$ & $\begin{array}{l}\text { WP smoking } \\
\text { session }\end{array}$ & $\begin{array}{l}\text { Cognitive - psychomotor } \\
\text { driving test }\end{array}$ & $\begin{array}{l}\text { Two-hand coordination total mean } \\
\text { duration score, but no other score, } \\
\text { improved after WP smoking. }\end{array}$ & $\begin{array}{l}\text { Controlled WP smoking session; } \\
\text { convenience sample; controlled for order of } \\
\text { test; objectively determined and controlled } \\
\text { for nicotine dependence. }\end{array}$ \\
\hline
\end{tabular}

*WPS: waterpipe smokers. CS: cigarette smokers. C: control. 
function between WP smoking and non-smoking male young adults before and immediately after supramaximal exercise in one of the studies ${ }^{84}$. The complexity of the cognitive test (number-recall) that was administered in the study may have been insufficient to detect a difference, and the sample size (10 per group) was small. However, the two-hands coordination, attention and concentration, reactive stress tolerance and reaction speed parameters on the Vienna Test System's traffic test battery improved after WP smoking among male college student participants in a pre-post study ${ }^{85}$. This effect was theorized as being due to the acute enhancement of fine motor performance, alerting attention accuracy, and response time, by nicotine. The potential chronic effect of WP smoking on these driving test parameters was not tested since the study did not include non-smoking controls. On the other hand, Meo et al. ${ }^{86}$ reported significant decline in attention switching, complex reaction time, and pattern recognition memory variables on the Cambridge Neuropsychological Automated Battery (CANTAB) test among WP smoking young adults compared to non-smoking controls.

Notwithstanding the inconsistencies in the results of the aforementioned studies, decreased circulating brain-derived neurotrophic factor (BDNF) among middle school adolescent smokers (vs nonsmokers) indicate the potential for adverse effect of WP smoking on mental health at a young age ${ }^{87}$. BDNF is a neurotrophin that is important for neural development and synaptogenesis, and plays a key role in learning and memory ${ }^{87,88}$. Consequently, a decline in its circulating concentration, which is correlated with BDNF levels in the brain, might be expected to result in cognitive and behavioral deficits ${ }^{87}$.

Comments about studies of neurological and psychological effects

It is unique that all the studies of the association between WP smoking and mental disorders were conducted in the US. All the studies of mental health were large population-based studies that relied on self-reported smoking status information. The four studies on cognitive and potential neurological effects were conducted in the Middle East, and three of these included only male participants. However, none but one evaluated the effect of gender or race on the associations between WP smoking effect and the outcomes. Primack et al. ${ }^{7}$ reported higher odds of WP smoking in college women versus men with addictive disorders.

\section{General health and systemic effects}

WP smoke contains considerably larger amounts of CO than cigarette smoke ${ }^{9}$. As would be expected, multiple cases of CO poisoning due to WP smoking among adolescents and young adults have been reported in the literature (Table 5) ${ }^{89-92}$. Also, WP smoking induces systemic oxidative stress and inflammatory responses (Table 5$)^{36,56,93-95}$. In one study, total oxidative status and antioxidant status, and their ratio (oxidative stress index), were increased by $205 \%, 15 \%$, and $180 \%$, respectively, in young adults following WP smoking compared to levels in non-smokers, whereas saltstimulated activity of antioxidant enzyme paraoxonase was correspondingly reduced ${ }^{36}$. However, the baseline pre-smoking levels of these biomarkers were not measured in the WP smokers. The expression of the xenobiotic-detoxifying enzymes $\mathrm{NAD}(\mathrm{P}) \mathrm{H}$ :quinone oxidoreductase 1 and glutathione S-transferase A1 in peripheral blood were also reduced in WP smokers compared to non-smoking controls in another small study (15 per group) comprised mostly of young adults $^{93}$.

Increased oxidative DNA damage in peripheral blood and lymphocytes has been reported in WP smoking young adults ${ }^{96-98}$. While no difference was observed in one study $^{21}$, increased chromosomal aberrations including chromosome and chromatid gaps and breaks, sister chromatid exchange and/ or chromosome fragments in blood cells were reported among young adult WP smokers in all other studies $^{96-98}$. Chromosomal aberrations were about $2 \mathrm{x}$ and about $4 \mathrm{x}$ more likely among those that used WP at least once a day compared to those who smoked 4-5 and $<3$ times per week, respectively ${ }^{96}$. Additionally, increased biomarker of DNA damage, 8-hydroxy-2'deoxyguanosine (8-OHdG), but reduced expression of DNA repair genes including oxoguanine glycosylase 1 and $\mathrm{X}$-ray repair cross complementing 1 protein, were observed in the blood of WP smokers compared to non-smoking controls ${ }^{93}$. The chromosomal aberrations were even more increased in WP smokers compared to cigarette smokers, which aligns with the higher yields of mutagenic and carcinogenic compounds in 
Table 5. Studies of systemic and general health effects of WP smoking in adolescents and young adults

\begin{tabular}{|c|c|c|c|c|c|c|}
\hline $\begin{array}{l}\text { Authors } \\
\text { Year }\end{array}$ & Study design & $\begin{array}{l}\text { Study participant } \\
\text { characteristics }\end{array}$ & $\begin{array}{l}\text { Exposure } \\
\text { measures }\end{array}$ & Outcomes of interest & Key results & Methodological information \\
\hline $\begin{array}{l}\text { Arziman et } \\
\text { al. }{ }^{89} \\
2011\end{array}$ & Case study & $\begin{array}{l}\mathrm{N}=4 ; 17-27 \text { years, age not } \\
\text { stated for one; } 25 \% \text { male; } \\
\text { Turkey }\end{array}$ & WP smoking & Systemic CO poisoning & $\begin{array}{l}\mathrm{COHb} \text { of } 11.4-21.3 \% \text { recorded and case } \\
\text { presented with various symptoms including } \\
\text { nausea, syncope, sinus and physical } \\
\text { tachycardia and vertigo. }\end{array}$ & Case study \\
\hline $\begin{array}{l}\text { de Suremain } \\
\text { et al. } .^{90} \\
2018\end{array}$ & Case study & 13-year-old male; Paris, France & WP smoking & Systemic CO poisoning & $\begin{array}{l}\mathrm{COHb} \text { of } 23.1 \% \text { recorded and case presented } \\
\text { with } \mathrm{CO} \text { poisoning after WP smoking. }\end{array}$ & Case study \\
\hline $\begin{array}{l}\text { Lim et al. }{ }^{91} \\
2019\end{array}$ & Case study & 19-year-old male; Singapore & WP smoking & Systemic CO poisoning & $\begin{array}{l}\mathrm{COHb} \text { of } 27.8 \% \text { recorded and case presented } \\
\text { with } \mathrm{CO} \text { poisoning after WP smoking. }\end{array}$ & Case study \\
\hline $\begin{array}{l}\text { van Rappard } \\
\text { et al. } .^{92} \\
2014\end{array}$ & Case study & $\begin{array}{l}N=4 ; 16-21 \text { years; } 50 \% \text { male; } \\
\text { Germany }\end{array}$ & WP smoking & Systemic CO poisoning & $\begin{array}{l}\text { COHb of } 16.7-29.6 \% \text { recorded; } 1 \\
\text { asymptomatic, } 3 \text { symptomatic presenting } \\
\text { with various symptoms including nausea, } \\
\text { syncope, headache and paresthesia. }\end{array}$ & Case study \\
\hline $\begin{array}{l}\text { Alomari et } \\
\text { al. }{ }^{95} \\
2018\end{array}$ & Cross-sectional & $\begin{array}{l}\mathrm{N}=475 \text { (WPS 93, CS 44, WP+CS } \\
173, \mathrm{C} 165) ; 12-17 \text { years } \\
\text { (mean: } 14.6 \pm 1 \text { ); } 55 \% \text { male; } \\
\text { Irbid, Jordan }\end{array}$ & WP smoking & $\begin{array}{l}\text { Serum vascular endothelial } \\
\text { growth factor (VEGF) }\end{array}$ & $\begin{array}{l}\text { VEGF }(\text { WPS }+C S<\text { WPS }<C S \text { or } C)-\text { result } \\
\text { due to difference in boys. }\end{array}$ & $\begin{array}{l}\text { Self-reported exposure only; } \\
\text { convenience sample used; control fo } \\
\text { confounding by age, gender, location } \\
\text { and BMI in statistical analysis. }\end{array}$ \\
\hline $\begin{array}{l}\text { Alsaad et } \\
\text { al. }^{93} \\
2019\end{array}$ & Cross-sectional & $\begin{array}{l}\mathrm{N}=45 \text { ( } 15 \text { WPS, } 15 \mathrm{CS}, 15 \\
\mathrm{C}) ; 18-40 \text { years }(\geq 80 \% \text { of all } \\
\text { groups } 20-29 \text { years); Riyadh, } \\
\text { Saudi Arabia }\end{array}$ & $\begin{array}{l}\text { Frequency of } \\
\text { WP smoking }\end{array}$ & $\begin{array}{l}\text { General - oxidative stress, } \\
\text { DNA repair gene expression, } \\
\text { xenobiotic activating and } \\
\text { detoxifying Enzyme gene } \\
\text { expression }\end{array}$ & $\begin{array}{l}\text { Blood 8-OHdG }(\mathrm{CS}>\text { WPS }>\text { C); expression } \\
\text { of DNA repair genes OGG1 and XRCC (WPS }< \\
\text { CS }<\text { C); expression of carcinogen activation/ } \\
\text { metabolism gene CYP1A1 }(\text { WPS }>\text { CS }>\text { C); } \\
\text { expression of detoxifying enzyme genes } \\
\text { (N001 - CS }<\text { WPS }<\text { C; GSTA1 - WPS }<\text { CS, } \\
\text { C). }\end{array}$ & $\begin{array}{l}\text { Self-reported exposure only; } \\
\text { convenience sample; no control for } \\
\text { confounding. }\end{array}$ \\
\hline $\begin{array}{l}\text { Alsatari et } \\
\text { al. }^{96} \\
2012\end{array}$ & Cross-sectional & $\begin{array}{l}\mathrm{N}=68(50 \text { WPS, } 18, \mathrm{CS}, 18 \\
\mathrm{C}) ; 26.5 \pm 4.2 \text { years for WPS, } \\
25.2 \pm 5.4 \text { for } \mathrm{CS}, 26.3 \pm 7.6 \text { for } \mathrm{C} ; \\
100 \% \text { male; Irbid City, Jordan }\end{array}$ & $\begin{array}{l}\text { WP smoking; } \\
\text { WP frequency } \\
\text { (high: } \geq 1 \\
\text { session/day; } \\
\text { medium: } 4-5 \\
\text { per week; low: } \\
<3 \text { per week) }\end{array}$ & Systemic genotoxicity & $\begin{array}{l}\text { Chromosomal aberrations }(\mathrm{CA}) \text { chromatid } \\
\text { and chromosome gaps and breaks and } \\
\text { exchange - WPS }(3.7 x)>C S(2.7 x)>C \text {; } C A- \\
\text { WP high }>\text { WP medium }>\text { WP low }\end{array}$ & $\begin{array}{l}\text { Self-reported exposure; participant } \\
\text { selection unspecified; participants } \\
\text { matched on age, exclusion of person } \\
\text { with alcohol and/or drug use. }\end{array}$ \\
\hline $\begin{array}{l}\text { Eker et al. }{ }^{22} \\
2016\end{array}$ & Cross-sectional & $\begin{array}{l}\mathrm{N}=60 \text { ( } 30 \text { WPS and } 30 \mathrm{C}) \\
18-25 \text { years; sex distribution } \\
\text { of both groups were similar; } \\
\text { Turkey }\end{array}$ & WP smoking & Systemic genotoxicity & $\begin{array}{l}\text { Chronic: no statistically significant difference } \\
\text { between the WPS and C groups in terms of } \\
\text { chromatid and chromosome breakages; WPS } \\
\text { > C for fragments and gaps. }\end{array}$ & $\begin{array}{l}\text { Self-reported exposure; participant } \\
\text { selection approach not stated; no } \\
\text { stated control of confounding. }\end{array}$ \\
\hline
\end{tabular}


Table 5. Continued

\begin{tabular}{|c|c|c|c|c|c|c|}
\hline $\begin{array}{l}\text { Authors } \\
\text { Year }\end{array}$ & Study design & $\begin{array}{l}\text { Study participant } \\
\text { characteristics }\end{array}$ & $\begin{array}{l}\text { Exposure } \\
\text { measures }\end{array}$ & Outcomes of interest & Key results & Methodological information \\
\hline $\begin{array}{l}\text { Hawari et } \\
\text { al. }^{42} \\
2019\end{array}$ & Cross-sectional & $\begin{array}{l}\mathrm{N}=738(135 \mathrm{WPS}, 303 \mathrm{CS}, \\
300 \mathrm{C}) ; 18-27 \text { years (mean: } \\
21.5 \pm 1.8 \text { for WPS, } 21.7 \pm 1.9 \\
\text { for } \mathrm{CS}, 21.6 \pm 1.9 \text { for } \mathrm{C}) ; 100 \% \\
\text { male; college campuses in } \\
\text { Egypt, Jordan, Morocco, Oman }\end{array}$ & $\begin{array}{l}\text { WP smoking, } \\
\text { WP duration, } \\
\text { WP frequency }\end{array}$ & $\begin{array}{l}\text { Quality of life (evaluated } \\
\text { using Short Form 12) }\end{array}$ & $\begin{array}{l}\text { WPS or CS > C for general health score; WPS } \\
>C \text { for emotional limitation domain score. }\end{array}$ & $\begin{array}{l}\text { Self-reported exposure; self-reported } \\
\text { outcome; convenience sample; } \\
\text { controlled for environmental } \\
\text { exposures, BMI, physical activities, } \\
\text { excluded persons with chronic } \\
\text { diseases. }\end{array}$ \\
\hline $\begin{array}{l}\text { Khabour et } \\
\text { al. }{ }^{97} \\
2011\end{array}$ & Cross-sectional & $\begin{array}{l}\mathrm{N}=86 \text { ( } 50 \text { WPS ( } 18 \text { heavy, } 16 \\
\text { medium, } 16 \text { light), } 18 \mathrm{CS} \text { and } \\
18 \mathrm{C}) ; 28.3 \pm 2.1 \text { years for WPS } \\
\text { heavy, } 26.1 \pm 1.7 \text { years for WPS } \\
\text { medium, } 24.9 \pm 1.8 \text { years for } \\
\text { WPS light, } 25.2 \pm 1.4 \text { years for } \\
\mathrm{CS} \text {, amd } 26.2 \pm 1.8 \text { years for } \mathrm{C} ; \\
100 \% \text { males; Irbid city/Jordan }\end{array}$ & $\begin{array}{l}\text { Frequency of } \\
\text { WPS per week }\end{array}$ & $\begin{array}{l}\text { Systemic genotoxicity (in } \\
\text { lymphocytes) }\end{array}$ & $\begin{array}{l}\text { Frequency of sister chromatid exchange - } \\
\text { WPS heavy }>\text { CS }>\text { C; WPS heavy }>\text { WPS } \\
\text { medium }>\text { WPS Light }>\text { C. Mitotic index: WPS } \\
+\mathrm{C}>\mathrm{C} \text { but not statistically different. }\end{array}$ & $\begin{array}{l}\text { Self-reported exposure; convenience } \\
\text { sample; no control for confounding. }\end{array}$ \\
\hline $\begin{array}{l}\text { Khalil et al. }{ }^{98} \\
2019\end{array}$ & Cross-sectional & $\begin{array}{l}\mathrm{N}=50 \text { ( } 25 \text { WPS group and } 25 \\
\mathrm{C} \text { ); Age range between } 18-25 \\
\text { years; gender distribution } \\
\text { not provided but reported to } \\
\text { be similar for both groups; } \\
\text { Philadelphia, Jordan }\end{array}$ & $\begin{array}{l}\text { WP smoking } \\
\text { (no cigarette } \\
\text { but smoke WP } \\
\text { for more than } 3 \\
\text { times per week } \\
\text { for more than } 2 \\
\text { years) }\end{array}$ & $\begin{array}{l}\text { Systemic genotoxicity (in } \\
\text { blood cells) }\end{array}$ & $\begin{array}{l}\text { WPS > C for chromosome breakage, } \\
\text { fragments, and gaps. }\end{array}$ & $\begin{array}{l}\text { Self-reported exposure; convenience } \\
\text { sample; stated that gender } \\
\text { distribution and sample size were } \\
\text { similar among both groups but no } \\
\text { control of potential confounding } \\
\text { factors otherwise. }\end{array}$ \\
\hline $\begin{array}{l}\text { Muddathir } \\
\text { al. } .^{94} \\
2018\end{array}$ & Cross-sectional & $\begin{array}{l}\mathrm{N}=120 \text { ( } 40 \text { WPS, } 40 \mathrm{CS} \text {, } \\
40 \mathrm{C} \text { ); WPS } 18-48 \text { years } \\
\text { (mean: } 27.8 \pm 3.9) ; \mathrm{CS} 18-47 \\
\text { years (mean: } 30.1 \pm 5.2) ; \mathrm{C} \\
19-51 \text { years (mean: } 29.6 \pm 4.5 \text { ); } \\
\text { Khartoum, Sudan }\end{array}$ & $\begin{array}{l}\text { WP smoking, } \\
\text { WP frequency } \\
\text { and duration }\end{array}$ & $\begin{array}{l}\text { Systemic - coagulation } \\
\text { factors fibrinogen, factor VII } \\
\text { and factors VIII }\end{array}$ & $\begin{array}{l}\text { WPS }>\text { CS }>C \text { for fibrogen, factor VII and } \\
\text { factors VIII; fibrinogen and factor VIII greater } \\
\text { in WPS for WP use }>3 \text { years vs } \leq 3 \text { years }\end{array}$ & $\begin{array}{l}\text { Self-reported exposure; convenience } \\
\text { sample; excluded individuals with } \\
\text { history of platelet abnormalities, } \\
\text { bleeding or vascular disorders, liver } \\
\text { or renal disease, medication affecting } \\
\text { platelet function. }\end{array}$ \\
\hline $\begin{array}{l}\text { Rajab et al. }{ }^{99} \\
2019\end{array}$ & Cross-sectional & $\begin{array}{l}\mathrm{N}=207 \text { ( } 88 \text { WPS, } 119 \mathrm{C} \text { ) 18-25 } \\
\text { years. 100\% female; Damascus, } \\
\text { Syria }\end{array}$ & WP smoking & $\begin{array}{l}\text { Systemic - folate levels } \\
\text { Systemic inflammation (hs- } \\
\text { CRP levels) }\end{array}$ & $\begin{array}{l}\text { Folate median WPS < overall group } \\
\text { hs-CRP levels not different between smokers } \\
\text { and non-smokers. }\end{array}$ & $\begin{array}{l}\text { Self-reported exposure to WP; } \\
\text { convenience sample used; no control } \\
\text { for confounding. }\end{array}$ \\
\hline
\end{tabular}


Table 5. Continued

\begin{tabular}{|c|c|c|c|c|c|c|}
\hline $\begin{array}{l}\text { Authors } \\
\text { Year }\end{array}$ & Study design & $\begin{array}{l}\text { Study participant } \\
\text { characteristics }\end{array}$ & $\begin{array}{l}\text { Exposure } \\
\text { measures }\end{array}$ & Outcomes of interest & Key results & Methodological information \\
\hline $\begin{array}{l}\text { Strulovici- } \\
\text { Barel et al. } .^{33} \\
2016\end{array}$ & Cross-sectional & $\begin{array}{l}\mathrm{N}=40 \text { participants ( } 19 \text { non- } \\
\text { smoker } \mathrm{C} \text { and } 21 \text { WPS); all } \\
\text { participants } \geq 18 \text { years (mean: } \\
33 \pm 9 \text { years in C group and } \\
25 \pm 4 \text { years in WPS group); } 90 \% \\
\text { male in } \mathrm{C}, 65 \% \text { male in WPS } \\
\text { group; } 6 / 5 / 8 \text { black/white/other } \\
\text { in C group and } 8 / 2 / 11 \text { black/ } \\
\text { white/other in WPS group; New } \\
\text { York City, USA }\end{array}$ & WPS smoking & $\begin{array}{l}\text { Systemic - plasma } \\
\text { endothelial microparticles } \\
\text { (EMPs) }\end{array}$ & WPS $>$ C for total EMP & $\begin{array}{l}\text { Self-reported exposure verified with } \\
\text { cotinine and nicotine measurements; } \\
\text { convenience sample used; no } \\
\text { confounder control but study } \\
\text { participants in C. }\end{array}$ \\
\hline $\begin{array}{l}\text { Yalcin et al. }{ }^{36} \\
2017\end{array}$ & $\begin{array}{l}\text { Cross-sectional, } \\
\text { pre-post }\end{array}$ & $\begin{array}{l}\mathrm{N}=100(50 \text { WPS/WPS }+\mathrm{CS} \text { and } \\
50 \mathrm{C}) 18-38 \text { years }(26.72 \pm 5.2 \\
\text { years for WPS, } 27.46 \pm 5.3 \text { years } \\
\text { for } \mathrm{C}) ; 66 \% \text { male for WPS, } 64 \% \\
\text { male for C; Ankara, Turkey }\end{array}$ & $\begin{array}{l}\text { WP smoking; } \\
\text { WP duration; } \\
\text { exhaled CO }\end{array}$ & Systemic oxidative stress & $\begin{array}{l}\text { After smoking, total oxidant and total } \\
\text { antioxidant statuses and oxidative } \\
\text { stress index higher, and salt-stimulated } \\
\text { paraoxonase activity lower in WPS. }\end{array}$ & $\begin{array}{l}\text { Controlled WP smoking session; } \\
\text { objective exhaled CO used to } \\
\text { quantify exposure but association } \\
\text { with outcome not analyzed; } \\
\text { convenience sample used; no control } \\
\text { for confounding. }\end{array}$ \\
\hline
\end{tabular}

*WPS: waterpipe smokers. CS: cigarette smokers. C: control. 
WP smoke ${ }^{96}$. In contrast, the blood concentration of 8-OHdG was higher in cigarette smokers, but this may be due to the reduced expression of DNA repair genes among WP smokers compared to cigarette smokers ${ }^{93}$. Furthermore, a dose-response relationship was observed between sister chromatid exchange and the frequency of WP smoking ${ }^{97}$.

Based on its oxidative effects, it is expected that WP smoking would induce systemic inflammation in adolescents and young adults. Nonetheless, no cross-shift change was observed in circulating

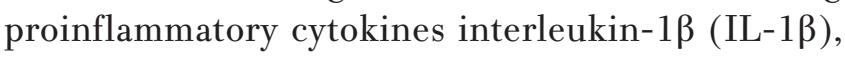
IL-6 and IL-8 among WP bar workers ${ }^{56}$, and the blood concentration of acute phase C-reactive protein was similar in female WP smoking and non-smoking university students ${ }^{99}$. However, interferon- $\gamma$ and tumor necrosis factor-a increased across the work shift among the bar workers ${ }^{56}$. Furthermore, there is an apparent effect of WP smoking on biological processes that are regulated by proinflammatory cytokines, including coagulation and angiogenesis ${ }^{100,101}$. Coagulation factors, fibrinogen, and factors VII and VIII, were increased in WP smokers compared to cigarette smokers and non-smokers with the levels of fibrinogen and factor VIII being associated with the duration of WP usage ${ }^{94}$. In contrast, vascular endothelial growth factor (VEGF), an angiogenic factor, was reduced in adolescents who smoked both cigarettes and WP, and those who smoked WP exclusively, compared to non-smoking controls ${ }^{95}$.

\section{Table 6. Implications of related subclinical physiological changes that are observed in relation to WP smoking in adolescents and young adults for chronic disease pathology}

\begin{tabular}{|c|c|}
\hline Outce & Implication/meaning \\
\hline $\begin{array}{l}\text { Iteration of s } \\
\text { ochemistry }\end{array}$ & $\begin{array}{l}\text { Changes in the acidity }(\mathrm{pH}) \text { and ability to buffer against it in the saliva can cause loss of enamel, increase } \\
\text { potential for infection and disease (e.g. oral thrush). Alteration of background microorganism composition } \\
\text { (microbiome) in the oral cavity as observed for WP may increase the risk of infection }{ }^{18,19} \text {. }\end{array}$ \\
\hline $\begin{array}{l}\text { Spirometry or lung } \\
\text { function }\end{array}$ & $\begin{array}{l}\text { Decline in lung function was often associated with WP smoking in the studies. Rapid (non-age related) decline } \\
\text { in lung function (volume capacity and air flow from the lungs) is involved in the pathogenesis of respiratory } \\
\text { diseases including asthma, chronic obstructive pulmonary disease (COPD), and lung cancer }{ }^{39} \text {. }\end{array}$ \\
\hline $\begin{array}{l}\text { Cellular composi } \\
\text { in small airway } \\
\text { epithelium }\end{array}$ & $\begin{array}{l}\text { The decrease in ciliated cells and increase in mucous secreting cells in small airway epithelium degrades the lung } \\
\text { clearance mechanism. Such alterations can be caused by exogenous insults, were observed in relation to WP } \\
\text { smoking, and do occur during the development of chronic respiratory diseases }{ }^{33} \text {. }\end{array}$ \\
\hline $\begin{array}{l}\text { Hematological } \\
\text { parameters }\end{array}$ & $\begin{array}{l}\text { WP increased hematological parameters including hematocrit (proportion of red blood cells in the blood) and } \\
\text { white blood cell counts. Chronic changes in these parameters alter cardiovascular function and may contribute } \\
\text { to or indicate disease }{ }^{84} \text {. }\end{array}$ \\
\hline $\begin{array}{l}\text { Hemodynamic } \\
\text { neasurements }\end{array}$ & $\begin{array}{l}\text { Measures of blood flow dynamics including BP are altered by WP smoking. An overly elevated BP (hypertension) } \\
\text { or reduced BP (hypotension) may precipitate or indicate chronic diseases including in the cardiovascular system }\end{array}$ \\
\hline $\begin{array}{l}\text { Vascular function } \\
\text { measures }\end{array}$ & $\begin{array}{l}\text { Measures of vascular function including FMD, arterial stiffness, and pulse wave velocity indicate the stiffness an } \\
\text { reactivity of blood vessels. Changes in vascular function is an early indicator of atherosclerotic cardiovascular } \\
\text { disease and is induced by WP smoking }{ }^{59,76} \text {. }\end{array}$ \\
\hline $\begin{array}{l}\text { Cardiac autonomic } \\
\text { control }\end{array}$ & $\begin{array}{l}\text { Change in the autonomic control of cardiovascular function is a predictor of coronary heart disease and } \\
\text { mortality and is induced by WP smoking }{ }^{60,77} \text {. }\end{array}$ \\
\hline $\begin{array}{l}\text { Brain-derived } \\
\text { neurotrophic factor } \\
\text { (BDNF) }\end{array}$ & $\begin{array}{l}\text { BDNF is involved in brain function and homeostasis. Reduced circulating BDNF concentration in the blood was } \\
\text { observed in association with WP smoking and may result in cognitive and behavioral deficit in the long-term }{ }^{87} \text {. }\end{array}$ \\
\hline Genotoxicity & $\begin{array}{l}\text { This includes damage to the structure of the DNA and chromosomes. Genotoxicity initiates the cancer } \\
\text { mechanism and its continuous induction by exogenous insults, similar to the observations for WP, can } \\
\text { overwhelm cellular defence mechanisms and increase cancer risk }{ }^{21,25} \text {. }\end{array}$ \\
\hline $\begin{array}{l}\text { Epigenetic } \\
\text { modification }\end{array}$ & $\begin{array}{l}\text { These are modifications on the DNA or histone that do not change the DNA sequence. They may affect gene } \\
\text { transcription and associated expression (production) of protein. Deleterious epigenetic changes, such as } \\
\text { was observed in relation to WP smoking, adversely alter cellular metabolism and are often involved in the } \\
\text { pathogenesis of chronic diseases including cancer and COPD }\end{array}$ \\
\hline $\begin{array}{l}\text { Oxidative stress } \\
\text { and inflammatory }\end{array}$ & $\begin{array}{l}\text { Oxidative stress (imbalance between production of oxidant species and antioxidant defences in the body) and } \\
\text { inflammation (triggering of the immune response) are involved in the pathogenesis of chronic inflammatory } \\
\text { diseases (e.g. cardiovascular disease, COPD, and cancer) and are both induced by WP smoking. }\end{array}$ \\
\hline
\end{tabular}


The effect that was associated with exclusive WP smoking was due to differences in boys and not girls. Although, the relationship between tobacco smoking and VEGF is inconsistent in the literature, Alomari et al. ${ }^{95}$ hypothesized that the increased amounts of $\mathrm{CO}$ and polycyclic aromatic hydrocarbons in WP smoke may inhibit the production and/or enhance the depletion of VEGF mRNA and protein in blood vessels. Finally, folate was reduced among female WP smoking university students compared to nonsmoking controls ${ }^{99}$, while WP smoking male young adults scored lower on the general health and emotional limitation domains of the 12 -item short form quality of life survey ${ }^{42}$.

\section{Comments about studies of general health and systemic effects}

All but three of the studies reporting on the general health and systemic effects of WP smoking were conducted in the Middle East ${ }^{56,90,92}$. All were either case studies or cross-sectional in design. While some included both male and female participants ${ }^{21,56,89,92,95}$, only one reported results about differences in the effect of WP smoking by gender ${ }^{95}$. Dose-response information was reported for only two of the studies ${ }^{94,97}$.

\section{CONCLUSION}

As expected in studies of adolescents and young adults, subclinical effects were the most investigated outcomes. Notwithstanding the weaknesses in the studies, results were consistent for the genotoxic effects of WP smoking which were observed to be more potent than cigarette smoking in a few studies. Similarly, results were consistent for effects on lung function and in the oral cavity. As reported in case studies, WP smoking can also result in acute clinical cases of lung injury and infection, and systemic CO poisoning. The plausibility of these effects, which are also reported for cigarette smoking, is obvious as WP smoke contains many of the same toxic components of cigarette smoke, and many of these in much larger amounts (e.g. particulate matter, CO, polycyclic aromatic hydrocarbons, and semi-volatile furans). Furthermore, these effects are involved in the pathogenesis of local and systemic chronic diseases (Table 6). Alteration of saliva biochemistry including its $\mathrm{pH}$, buffering capacity, and the oral microbiome, increases the risk of tooth decay and oral infection ${ }^{18,19}$, while decline in lung function (spirometry measures) above age-related decrease and adverse changes in cellular composition in the small airways of the lungs, which are indicative of impairment in clearance mechanisms, contribute to the development of chronic lung diseases ${ }^{33,39}$. Also, chronic hematological changes, elevated BP, impaired vascular function, and altered cardiac autonomic function can be induced by continuous exposure to exogenous insults and are risk factors for cardiovascular disease ${ }^{59,63,76,77,84}$. Finally, chronic induction of genotoxicity, including damage to the DNA and chromosomes and deleterious epigenetic modification, is integral to the development of cancer ${ }^{21,25,32,33}$. Although asthma and type 2 diabetes are associated with cigarette smoking in young adults $^{102-105}$, studies of the relationships between WP smoking and both diseases are lacking. Nonetheless, findings from two cross-sectional surveys of high school students in Florida suggest that there might be an association with asthma $a^{50,51}$.

While 65 studies met the criteria for selection in this narrative review, the literature on this topic is still quite nascent. Most of the studies are case studies, cross-sectional, or pre-post in design; one is a crossover study while only two are longitudinal in design. Most relied on convenience samples, included only male or only female participants, and/or relied solely on selfreported smoking as the exposure metric. Therefore, information about exposure-response relationships and differences by demographic factors are mostly lacking. Also, there is a dearth of information about the effect of WP smoking among young adults in Western countries such as the US, the demographic group experiencing the greatest growth in prevalence of WP use. However, confounding of the associations of outcomes with WP usage, due to the smoking of alternative tobacco products, was mitigated in most of the studies. Twenty-two of the selected studies were case or pre-post studies that investigated outcomes following WP use, while smoking more than one tobacco product was an exclusion criterion, or controlled for, in 31 of the remaining 43 studies.

To comprehensively understand the effect of WP smoking, the generalizability of findings must be improved by conducting more studies outside the Middle East, in countries where there has been a recent rapid uptake of WP smoking among 
adolescents and young adults. In addition, future research should include sufficient sample sizes of participants distributed equally among the sexes so that gender differences can be explored, should be longitudinal in design, and should sufficiently control for confounders including the objective measurement of tobacco smoking, such as urinary or salivary cotinine. The results from such studies will underpin the development of effective regulations and effective educational campaigns designed to curb WP smoking among young adults.

\section{REFERENCES}

1. Yadav S, Rawal G. Waterpipe Tobacco Smoking: A Mini-review. J Transl Int Med. 2018;6(4):173-175. doi:10.1515/jtim-2016-0013

2. Maziak W, Taleb ZB, Bahelah R, et al. The global epidemiology of waterpipe smoking. Tob Control. 2015;24 Suppl 1(Suppl 1):i3-i12. doi:10.1136/tobaccocontrol-2014-051903

3. Jawad M, Charide R, Waziry R, Darzi A, Ballout RA, Akl EA. The prevalence and trends of waterpipe tobacco smoking: A systematic review. PLoS One. 2018;13(2):e0192191. doi:10.1371/journal.pone.0192191

4. Bhatnagar A, Maziak W, Eissenberg T, et al. Water pipe (hookah) smoking and cardiovascular disease risk: a scientific statement from the American Heart Association. Circulation. 2019;139(19):e917-e936. doi:10.1161/cir.0000000000000671

5. Sharma E, Bansal-Travers M, Edwards KC, et al. Longitudinal pathways of exclusive and polytobacco hookah use among youth, young adults and adults in the USA: findings from the PATH Study Waves 1-3 (20132016). Tob Control. 2020;29(Suppl 3):s155-s162. doi:10.1136/tobaccocontrol-2020-055625

6. Azagba S, Latham K, Shan L. Waterpipe tobacco smoking trends among middle and high school students in the United States from 2011 to 2017. Drug Alcohol Depend. 2019;200:19-25. doi:10.1016/j.drugalcdep.2019.04.005

7. Primack BA, Carroll MV, Weiss PM, et al. Systematic review and meta-analysis of inhaled toxicants from waterpipe and cigarette smoking. Public Health Rep. 2016;131(1):76-85. doi:10.1177/003335491613100114

8. Katurji M, Daher N, Sheheitli H, Saleh R, Shihadeh A. Direct measurement of toxicants inhaled by water pipe users in the natural environment using a real-time in situ sampling technique. Inhal Toxicol. 2010;22(13):11011109. doi:10.3109/08958378.2010.524265

9. Shihadeh A, Saleh R. Polycyclic aromatic hydrocarbons, carbon monoxide, "tar", and nicotine in the mainstream smoke aerosol of the narghile water pipe. Food Chem Toxicol. 2005;43(5):655-661. doi:10.1016/j.fct.2004.12.013

10. Shihadeh A. Investigation of mainstream smoke aerosol of the argileh water pipe. Food Chem Toxicol. 2003;41(1):143-
152. doi:10.1016/s0278-6915(02)00220-x

11. Brinkman MC, Teferra AA, Kassem NO, Kassem NO. Effect of electric heating and ice added to the bowl on mainstream waterpipe semivolatile furan and other toxicant yields. Tob Control. 2020;29(Suppl 2):s110-s116. doi:10.1136/tobaccocontrol-2019-054961

12. El-Zaatari ZM, Chami HA, Zaatari GS. Health effects associated with waterpipe smoking. Tob Control. 2015;24 Suppl 1(Suppl 1):i31-i43. doi:10.1136/tobaccocontrol-2014-051908

13. Waziry R, Jawad M, Ballout RA, Al Akel M, Akl EA. The effects of waterpipe tobacco smoking on health outcomes: an updated systematic review and meta-analysis. Int J Epidemiol. 2017;46(1):32-43. doi:10.1093/ije/dyw021

14. Vespa J. The changing economics and demographics of young adulthood: 1975-2016. US Department of Commerce, Economics and Statistics Administration; 2017. Accessed April 23, 2021. https://www.census.gov/ content/dam/Census/library/publications/2017/demo/ p20-579.pdf

15. Akram Z, Javed F, Vohra F. Effect of waterpipe smoking on peri-implant health: A systematic review and metaanalysis. J Investig Clin Dent. 2019;10(3):e12403. doi:10.1111/jicd.12403

16. Haddad L, Kelly DL, Weglicki LS, Barnett TE, Ferrell AV, Ghadban R. A systematic review of effects of waterpipe smoking on cardiovascular and respiratory health outcomes. Tob Use Insights. 2016;9. doi:10.4137/tui.s39873

17. Kim KH, Kabir E, Jahan SA. Waterpipe tobacco smoking and its human health impacts. J Hazard Mater. 2016;317:229-236. doi:10.1016/j.jhazmat.2016.05.075

18. Seifi S, Feizi F, Mehdizadeh M, Khafri S, Ahmadi B. Evaluation of cytological alterations of oral mucosa in smokers and waterpipe users. Cell J. 2014;15(4):302. Accessed April 23, 2021. https://www.ncbi.nlm.nih.gov/ pmc/articles/PMC3866533/pdf/Cell-J-15-302.pdf

19. Silveira MA, Antonelli AS, Fiorelli BO, d'Arce LP. Cytological multimarker screening using BMCyt test in waterpipe smokers: an integrative study of cell damage, toxicological and cancer risk. J Genet. 2018;97(2):399404. doi:10.1007/s12041-018-0923-y

20. Taghibakhsh M, Farhadi S, Babaee A, Sheikhi M. The effect of hookah use on buccal mucosa: evaluation of repair index. Asian Pac J Cancer Prev. 2019;20(4):1109. doi:10.31557/apjcp.2019.20.4.1109

21. Dehghan Nezhad M, Naderi NJ, Semyari H. Micronucleus assay of buccal mucosa cells in waterpipe (hookah) smokers: a cytologic study. Iran J Pathol. 2020;15(2):75. doi:10.30699/ijp.2020.101701.2010

22. Derici Eker E, Koyuncu H, Şahin NÖ, et al. Determination of Genotoxic Effects of Hookah Smoking by Micronucleus and Chromosome Aberration Methods. Med Sci Monit. 2016;22:4490. doi:10.12659/msm.898593

23. Rajabi-Moghaddam M, Haji Mirzamohammad M, Yahyazadeh E, Gholinia H, Abbaszadeh H. Comparison 
of Genotoxic Effect in Buccal Exfoliated Cells between Cigarette and Waterpipe Smokers. Acta Cytol. 2020;64(5):471-476. doi:10.1159/000506893

24. Jafari S, Arbabi Bidgoli S. Micronucleus Investigation in buccal mucosal cells of young waterpipe tobacco smokers in Tehran. J Pharm Health Sci. 2017;5(3):217-224.

25. Arazi H, Taati B, Rafati Sajedi F, Suzuki K. Salivary Antioxidants status following progressive aerobic exercise: what are the differences between waterpipe smokers and non-smokers? Antioxidants. 2019;8(10):418. doi:10.3390/antiox8100418

26. Khemiss M, Ben Khelifa M, Ben Saad H. Preliminary findings on the correlation of saliva $\mathrm{pH}$, buffering capacity, flow rate and consistency in relation to waterpipe tobacco smoking. Libyan J Med. 2017;12(1):1289651. doi:10.1080/19932820.2017.1289651

27. Shakhatreh MAK, Khabour OF, Alzoubi KH, Masadeh MM, Hussein EI, Bshara GN. Alterations in oral microbial flora induced by waterpipe tobacco smoking. Int J Gen Med. 2018;11:47. doi:10.2147/IJGM.S150553

28. Han YW. Fusobacterium nucleatum: a commensal-turned pathogen. Current Opin Microbiol. 2015;23:141-147. doi:10.1016/j.mib.2014.11.013

29. Khemiss M, Ben Fekih D, Ben Khelifa M, Ben Saad H. Comparison of Periodontal Status Between Male Exclusive Narghile Smokers and Male Exclusive Cigarette Smokers. Am J Mens Health. 2019;13(2):1557988319839872. doi:10.1177/1557988319839872

30. Khemiss M, Ben Khelifa M, Ben Rejeb M, Ben Saad H. Periodontal bone height of exclusive narghile smokers compared with exclusive cigarette smokers. Libyan J Med. 2016;11:31689. doi:10.3402/ljm.v11.31689

31. Al-Belasy FA. The relationship of "shisha" (water pipe) smoking to postextraction dry socket. J Oral Maxillofac Surg. 2004;62(1):10-14. doi:10.1016/j.joms.2002.11.001

32. Walters MS, Salit J, Ju JH, et al. Waterpipe smoking induces epigenetic changes in the small airway epithelium. PloS One. 2017;12(3):e0171112. doi:10.1371/journal.pone.0171112

33. Strulovici-Barel Y, Shaykhiev R, Salit J, et al. Pulmonary Abnormalities in Young, Light-Use Waterpipe (Hookah) Smokers. Am J Respir Crit Care Med. 2016;194(5):587595. doi:10.1164/rccm.201512-24700C

34. Meo SA, AlShehri KA, AlHarbi BB, et al. Effect of shisha (waterpipe) smoking on lung functions and fractional exhaled nitric oxide (FeNO) among Saudi young adult shisha smokers. Int J Environ Res Public Health. 2014;11(9):9638-9648. doi:10.3390/ijerph110909638

35. Ricciardolo FLM. Multiple roles of nitric oxide in the airways. Thorax. 2003;58(2):175-182. doi:10.1136/thorax.58.2.175

36. Yalcin FK, Er M, Hasanoglu HC, et al. Deteriorations of pulmonary function, elevated carbon monoxide levels and increased oxidative stress amongst water-pipe smokers. Int J Occup Med Environ Health. 2017;30(5):731. doi:10.13075/ijomeh.1896.00912

37. Husain H, Al-Fadhli F, Al-Olaimi F, et al. Is Smoking Shisha Safer than Cigarettes: Comparison of Health Effects of Shisha and Cigarette Smoking among Young Adults in Kuwait. Med Princ Pract. 2016;25(2):117-122. doi:10.1159/000442417

38. Hawari FI, Obeidat NA, Ayub H, et al. The acute effects of waterpipe smoking on lung function and exercise capacity in a pilot study of healthy participants. Inhal Toxicol. 2013;25(9):492-497. doi:10.3109/08958378.2013.806613

39. Hawari FI, Obeidat NA, Ghonimat IM, Ayub HS, Dawahreh SS. The effect of habitual waterpipe tobacco smoking on pulmonary function and exercise capacity in young healthy males: A pilot study. Respir Med. 2017;122:7175. doi:10.1016/j.rmed.2016.11.024

40. Bahtouee M, Maleki N, Nekouee F. The prevalence of chronic obstructive pulmonary disease in hookah smokers. Chron Respir Dis. 2018;15(2):165-172. doi:10.1177/1479972317709652

41. Raad D, Gaddam S, Schunemann HJ, et al. Effects of water-pipe smoking on lung function: a systematic review and meta-analysis. Chest. 2011;139(4):764-774. doi:10.1378/chest.10-0991

42. Hawari FI, Obeidat NA, Abu Alhalawa M, et al. Respiratory health and quality of life in young exclusive, habitual smokers - a comparison of waterpipe smokers, cigarette smokers and non-smokers. Int J Chron Obstruct Pulmon Dis. 2019;14:1813-1824. doi:10.2147/COPD.S205050

43. Tamim H, Musharrafieh U, El Roueiheb Z, Yunis K, Almawi WY. Exposure of children to environmental tobacco smoke (ETS) and its association with respiratory ailments. J Asthma. 2003;40(5):571-576. doi:10.1081/jas-120019029

44. Alaska YA. Spontaneous Pneumomediastinum Secondary to Hookah Smoking. Am J Case Rep. 2019;20:651. doi:10.12659/AJCR.915118

45. Choe EH, Sutherland L, Hills C, Sood JD. Shisha smoking as a possible cause of bilateral granulomatous lung lesions. Respirol Case Rep. 2018;6(9):e00374. doi:10.1002/rcr2.374

46. Annakkaya AN, Balbay EG, Öztürk Ö, Önal B, Aytekin F, Balbay Ö. Waterpipe (narghile, hookah) tobacco smokinginduced acute eosinophilic pneumonia. Eurasian Journal of Pulmonology. 2018;20(1):46. doi:10.4103/ejop.ejop_3_18

47. Kang M, Raj V, Berman AR. A Man in His 20s With Diffuse Lung Opacities and Acute Respiratory Failure After Hookah Smoking. Chest. 2016;150(6):e175-e178. doi:10.1016/j.chest.2016.10.009

48. Brosh-Nissimov T, Grupel D, Abuhasira S, et al. Case report: imported melioidosis from Goa, India to Israel, 2018. Am J Trop Med Hyg. 2019;101(3):580-584. doi:10.4269/ajtmh.19-0303

49. Marchetti AU, Boss OL, Schenker CM, Kälin K. Water-pipe Smoking as a Risk Factor for Transmitting Mycobacterium tuberculosis. Eur J Case Rep Intern Med. 
2020;7(1).doi:10.12890/2019_001342

50. Fedele DA, Barnett TE, Dekevich D, Gibson-Young LM, Martinasek M, Jagger MA. Prevalence of and beliefs about electronic cigarettes and hookah among high school students with asthma. Ann Epidemiol. 2016;26(12):865869. doi:10.1016/j.annepidem.2016.10.004

51. Martinasek MP, Gibson-Young L, Forrest J. Hookah smoking and harm perception among asthmatic adolescents: findings from the Florida youth tobacco survey. J Sch Health. 2014;84(5):334-341. doi:10.1111/josh.12153

52. Rezk-Hanna M, Nelson MD, Rader F, et al. Peripheral blood flow changes to cutaneous and muscular beds in response to acute hookah smoking. Am J Cardiol. 2020;125(11). doi:10.1016/j.amjcard.2020.02.042

53. Nelson MD, Rezk-Hanna M, Rader F, et al. Acute Effect of Hookah Smoking on the Human Coronary Microcirculation. Am J Cardiol. 2016;117(11):17471754. doi:10.1016/j.amjcard.2016.03.007

54. Alomari MA, Khabour OF, Alzoubi KH, Shqair DM, Eissenberg T. Central and peripheral cardiovascular changes immediately after waterpipe smoking. Inhal Toxicol. 2014;26(10):579-587. doi:10.3109/08958378.2014.936572

55. Alomari MA, Khabour OF, Alzoubi KH, Shqair DM, Stoner L. Acute vascular effects of waterpipe smoking: Importance of physical activity and fitness status. Atherosclerosis. 2015;240(2):472-476. doi:10.1016/j.atherosclerosis.2015.02.047

56. Zhou S, Behrooz L, Weitzman M, et al. Secondhand hookah smoke: an occupational hazard for hookah bar employees. Tob Control. 2017;26(1):40-45. doi:10.1136/tobaccocontrol-2015-052505

57. Kadhum M, Jaffery A, Haq A, Bacon J, Madden B. Measuring the acute cardiovascular effects of shisha smoking: a crosssectional study. JRSM Open. 2014;5(6):2054270414531127. doi: $10.1177 / 2054270414531127$

58. Rezk-Hanna M, Doering L, Robbins W, Sarna L, Elashoff RM, Victor RG. Acute Effect of Hookah Smoking on Arterial Stiffness and Wave Reflections in Adults Aged 18 to 34 Years of Age. Am J Cardiol. 2018;122(5):905909. doi:10.1016/j.amjcard.2018.05.033

59. Rezk-Hanna M, Mosenifar Z, Benowitz NL, et al. High Carbon Monoxide Levels from Charcoal Combustion Mask Acute Endothelial Dysfunction Induced by Hookah (Waterpipe) Smoking in Young Adults. Circulation. 2019;139(19):2215-2224. doi:10.1161/CIRCULATIONAHA

60. Cobb CO, Sahmarani K, Eissenberg T, Shihadeh A. Acute toxicant exposure and cardiac autonomic dysfunction from smoking a single narghile waterpipe with tobacco and with a "healthy" tobacco-free alternative. Toxicol Lett. 2012;215(1):70-75. doi:10.1016/j.toxlet.2012.09.026

61. Al-Safi SA, Ayoub NM, Albalas MA, Al-Doghim I, AboulEnein FH. Does shisha smoking affect blood pressure and heart rate? J Public Health. 2009;17(2):121-126. doi:10.1007/s10389-008-0220-y

62. Alomari MA, Al-Sheyab NA. Impact of waterpipe smoking on blood pressure and heart rate among adolescents: The Irbid-TRY. J Subst Use. 2018;23(3):280-285. doi:10.1080/14659891.2017.1394379

63. Alomari MA, Al-Sheyab NA, Mokdad AH. Gender-Specific Blood Pressure and Heart Rate Differences in Adolescents Smoking Cigarettes, Waterpipes or Both. Subst Use Misuse. 2020;55(2):296-303. doi:10.1080/10826084.2019.1666146

64. Alomari MA, Al-Sheyab NA. Cigarette smoking lowers blood pressure in adolescents: the Irbid-TRY. Inhal Toxicol. 2016;28(3):140-144. doi:10.3109/08958378.2016.1145769

65. Benowitz NL, Burbank AD. Cardiovascular toxicity of nicotine: Implications for electronic cigarette use. Trends Cardiovasc Med. 2016;26(6):515-523. doi:10.1016/j.tcm.2016.03.001

66. Hughes K, Leong WP, Sothy SP, Lun KC, Yeo PP. Relationships between cigarette smoking, blood pressure and serum lipids in the Singapore general population. Int J Epidemiol. 1993;22(4):637-643. doi:10.1093/ije/22.4.637

67. Imamura H, Tanaka K, Hirae C, et al. Relationship of cigarette smoking to blood pressure and serum lipids and lipoproteins in men. Clin Exp Pharmacol Physiol. 1996;23(5):397-402. doi:10.1111/j.1440-1681.1996.tb02748.x

68. Li G, Wang H, Wang $\mathrm{K}$, et al. The association between smoking and blood pressure in men: a crosssectional study. BMC Public Health. 2017;17(1):797. doi:10.1186/s12889-017-4802-x

69. Nadruz W Jr, Gonçalves A, Claggett B, et al. Influence of cigarette smoking on cardiac biomarkers: the Atherosclerosis Risk in Communities (ARIC) Study. Eur J Heart Fail. 2016;18(6):629-637. doi:10.1002/ejhf.511

70. Omvik P. How smoking affects blood pressure. Blood Press. 1996;5(2):71-77. doi:10.3109/08037059609062111

71. Virdis A, Giannarelli C, Neves MF, Taddei S, Ghiadoni L. Cigarette smoking and hypertension. Curr Pharm Des. 2010;16(23):2518-2525. doi:10.2174/138161210792062920

72. Kannel WB, D'Agostino RB, Silbershatz H. Blood pressure and cardiovascular morbidity and mortality rates in the elderly. Am Heart J. 1997;134(4):758-763. doi:10.1016/s0002-8703(97)70061-9

73. Chrysant SG, Chrysant GS. Effectiveness of lowering blood pressure to prevent stroke versus to prevent coronary events. Am J Cardiol. 2010;106(6):825-829. doi:10.1016/j.amjcard.2010.05.006

74. Dorresteijn JA, van der Graaf Y, Spiering W, Grobbee DE, Bots ML, Visseren FL; Secondary Manifestations of Arterial Disease Study Group. Relation between blood pressure and vascular events and mortality in patients with manifest vascular disease: J-curve revisited. Hypertension. 2012;59(1):14-21. doi:10.1161/HYPERTENSIONAHA.111.179143

75. Egan BM, Kai B, Wagner CS, et al. Low blood pressure is associated with greater risk for cardiovascular events 
in treated adults with and without apparent treatmentresistant hypertension. J Clin Hypertens. 2017;19(3):241249. doi:10.1111/jch.12904

76. Selim GM, Elia RZ, El Bohey AS, El Meniawy KA. Effect of shisha vs. cigarette smoking on endothelial function by brachial artery duplex ultrasonography: an observational study. Anadolu Kardiyol Derg. 2013;13(8):759-765. doi:10.5152/akd.2013.4499

77. Yıldırım F, Çevik Y, Emektar E, Çorbacıŏlu ŞK, Katırıı Y. Evaluating ECG and carboxyhemoglobin changes due to smoking narghile. Inhal Toxicol. 2016;28(12):546-549. doi:10.1080/08958378.2016.1224957

78. Bandiera FC, Loukas A, Wilkinson AV, Perry CL. Associations between tobacco and nicotine product use and depressive symptoms among college students in Texas. Addict Behav. 2016;63:19-22. doi:10.1016/j.addbeh.2016.06.024

79. Marsden DG, Loukas A, Chen B, Perry CL, Wilkinson AV. Associations between frequency of cigarette and alternative tobacco product use and depressive symptoms: A longitudinal study of young adults. Addict Behav. 2019;99:106078. doi:10.1016/j.addbeh.2019.106078

80. Primack BA, Land SR, Fan J, Kim KH, Rosen D. Associations of mental health problems with waterpipe tobacco and cigarette smoking among college students. Subst Use Misuse. 2013;48(3):211-219. doi:10.3109/10826084.2012.750363

81. Goodwin RD, Grinberg A, Shapiro J, et al. Hookah use among college students: prevalence, drug use, and mental health. Drug Alcohol Depend. 2014;141:16-20. doi:10.1016/j.drugalcdep.2014.04.024

82. Heinz AJ, Giedgowd GE, Crane NA, et al. A comprehensive examination of hookah smoking in college students: use patterns and contexts, social norms and attitudes, harm perception, psychological correlates and co-occurring substance use. Addict Behav. 2013;38(11):2751-2760. doi:10.1016/j.addbeh.2013.07.009

83. King JL, Reboussin BA, Spangler J, Cornacchione Ross J, Sutfin EL. Tobacco product use and mental health status among young adults. Addict Behav. 2018;77:6772. doi:10.1016/j.addbeh.2017.09.012

84. Ahmadian M, Ghorbani S, Beiki Y, Brandes M, Saeidi A, Leicht A. Influence of waterpipe smoking on hematological parameters and cognitive function before and after supramaximal exercise. Sci Sports. 2017;32(4):e147-e154. doi:10.1016/j.scispo.2017.03.001

85. Saadat S, Sabagh M, Karbakhsh M. The effect of waterpipe smoking on psychomotor performance required for driving: a quasi-experimental trial. J Transp Health. 2018;9:180-186. doi:10.1016/j.jth.2018.02.002

86. Meo SA, Bashir S, Almubarak Z, Alsubaie Y, Almutawa H. Shisha smoking: impact on cognitive functions impairments in healthy adults. Eur Rev Med Pharmacol Sci. 2017;21(22):5217-5222. doi:10.26355/eurrev_201711_13844
87. Alomari MA, Al-Sheyab NA, Khabour OF, Alzoubi KH. Brain-derived neutrophic factor in adolescents smoking waterpipe: The Irbid TRY. Int J Dev Neurosci. 2018;67:14-18. doi:10.1016/j.ijdevneu.2018.03.007

88. Binder DK, Scharfman HE. Brain-derived neurotrophic factor. Growth Factors. 2004;22(3):123-131. doi:10.1080/08977190410001723308

89. Arziman I, Acar Y, Yildirim A, et al. Five cases of carbon monoxide poisoning due to narghile (shisha). Hong Kong Journal of Emergency Medicine. 2011;18(4):254-257. doi:10.1177/102490791101800412

90. de Suremain N, Ngo J, Loschi S, Haegy-Doehring I, Aroulandom J, Carbajal R. Carbon monoxide poisoning from waterpipe (narghile) smoking in a child. Arch Pediatr. 2019;26(1):44-47. doi:10.1016/j.arcped.2018.11.008

91. Lim BL, Lim GH, Seow E. Case of carbon monoxide poisoning after smoking shisha. Int J Emerg Med. 2009;2(2):121-122. 2009;2(2). doi:10.1007/s12245-009-0097-8

92. von Rappard J, Schönenberger M, Bärlocher L. Carbon monoxide poisoning following use of a water pipe/hookah. Dtsch Arztebl Int. 2014;111(40):674. doi:10.3238/arztebl.2014.0674

93. Alsaad AM, Al-Arifi MN, Maayah ZH, et al. Genotoxic impact of long-term cigarette and waterpipe smoking on DNA damage and oxidative stress in healthy subjects. Toxicol Mech Methods. 2019;29(2):119-127. doi:10.1080/15376516.2018.1528650

94. Muddathir ARM, Abd Alla MI, Khabour OF. Waterpipe Smoking Is Associated with Changes in Fibrinogen, FVII, and FVIII Levels. Acta Haematol. 2018;140(3):159-165. doi:10.1159/000492740

95. Alomari MA, Al-Sheyab NA, Khabour OF, Alzoubi KH. Serum VEGF Level Is Different in Adolescents Smoking Waterpipe versus Cigarettes: The Irbid TRY. Biomolecules. 2018;8(4):102. doi:10.3390/biom8040102

96. Alsatari ES, Azab M, Khabour OF, Alzoubi KH, Sadiq MF. Assessment of DNA damage using chromosomal aberrations assay in lymphocytes of waterpipe smokers. Int J Occup Med Environ Health. 2012;25(3):218-224. doi:10.2478/S13382-012-0027-5

97. Khabour OF, Alsatari ES, Azab M, Alzoubi KH, Sadiq MF. Assessment of genotoxicity of waterpipe and cigarette smoking in lymphocytes using the sister-chromatid exchange assay: a comparative study. Environ Mol Mutagen. 2011;52(3):224-228. doi:10.1002/em.20601

98. Khalil R, Ali D, Al bsoul E, Ghanayem R, Ghanayem R. The effect of waterpipe smoking on DNA integrity among youth in Jordan. Arab J Sci Eng. 2019;44(7):6253-6257. doi:10.1007/s13369-019-03794-x

99. Rajab M, Jumaa M, Horaniah MY, Barakat A, Bakleh S, Zarzour W. Correlations of C-Reactive protein and folate with smoking, sport, hematological inflammation biomarkers and anthropometrics in Syrian university female students cross-sectional study. Sci Rep. 2019;9:1- 
11. doi:10.1038/s41598-019-51658-z

100. van der Poll T, de Jonge E, ten Cate an H. Cytokines as Regulators of Coagulation. In: Madame Curie Bioscience Database. Saftig P, ed. Landes Bioscience; 2013.

101.Maloney JP, Gao L. Proinflammatory cytokines increase vascular endothelial growth factor expression in alveolar epithelial cells. Mediators Inflamm. 2015. doi:10.1155/2015/387842

102.Gilliland FD, Islam T, Berhane K, et al. Regular smoking and asthma incidence in adolescents. Am J Respir Crit Care Med. 2006;174(10):1094-1100. doi:10.1164/rccm.200605-722oc

103.Śliwińska-Mossoń M, Milnerowicz H. The impact of smoking on the development of diabetes and its complications. Diab Vasc Dis Res. 2017;14(4):265-276. doi:10.1177/1479164117701876

104.Willi C, Bodenmann P, Ghali WA, Faris PD, Cornuz J. Active smoking and the risk of type 2 diabetes: a systematic review and meta-analysis. JAMA. 2007;298(22):26542664. doi:10.1001/jama.298.22.2654

105.Hedman L, Bjerg A, Sundberg S, Forsberg B, Rönmark E. Both environmental tobacco smoke and personal smoking is related to asthma and wheeze in teenagers. Thorax. 2011;66(1):20-25. doi:10.1136/thx.2010.14380

\section{CONFLICTS OF INTEREST}

The authors have each completed and submitted an ICMJE form for disclosure of potential conflicts of interest. The authors declare that they have no competing interests, financial or otherwise, related to the current work. O. Adetona, S. Mok, J. Rajczyk and M.C. Brinkman report that since the initial planning of the work a grant was paid to their institution by the US National Institutes of Health. A.K. Ferketich reports that since the initial planning of the work she received from NIH a grant (R01CA229306).

\section{FUNDING}

Research reported in this publication was supported by the National Cancer Institute of the National Institutes of Health under Award Number R01CA229306 and 3R01229306-03S1. The content is solely the responsibility of the authors and does not necessarily represent the official views of the National Institutes of Health.

ETHICAL APPROVAL AND INFORMED CONSENT

Ethical approval and informed consent were not required as this is a review article of existing literature.

\section{DATA AVAILABILITY}

Data sharing is not applicable to this article as no new data were created.

\section{AUTHORS' CONTRIBUTIONS}

$O A, M C B$ and $A K F$ were responsible for the conception of this work. SM and JR conducted the literature search. OA, SM and JR abstracted the data from selected papers. OA drafted the manuscript, with SM and JR contributing. MCB and AKF critically reviewed the manuscript. All authors read and approved the final version of the manuscript.

PROVENANCE AND PEER REVIEW

Not commissioned; externally peer reviewed. 